\title{
An Asset-Based Approach to the Tax Benefit Rule
}

For sixty years, the tax benefit rule has required taxpayers to recognize mcome when they "recover" an item or amount deducted in a previous year. This rule was created to remedy mequities in taxation engendered by the annual accounting system. While the rule long remaimed a sound approach to multiyear dealings, its apphication to colnplex transactions began to stram its theoretical underpinnings. In addition, while some cases held that a recovery was necessary to trigger the rule, others indicated that an actual recovery might not be required.

Last year in Hillsboro National Bank v. Commissioner and United States v. Bliss Dairy, Inc., ${ }^{1}$ the United States Supreme Court faced the paradigm illustratimg the weaknesses of the tax benefit rule-a corporate liquidation. Corporate liquidations have never fallen within the categorical requirements of the recovery tax benefit rule because there is rarely a "recovery" when the taxpayer goes out of existence. Nevertheless, hquidations can produce the potential mequities that require application of the tax benefit rule. To solve this difficulty, the Supreme Court abandoned the recovery approach and redefined the tax benefit rule as applying whenever an event that is "fundamentally inconsistent" with the previous deduction occurs. ${ }^{2}$ While many commentators have discussed the inconsistent events approach, ${ }^{3}$ the scope of the new rule is still unclear and it has not yet been translated imto a rule of practical apphication.

The Court's struggle to apply its purely theoretical approach to concrete fact situations demonstrates the fatal flaw in the new rule: it does not survive the translation from concept to everyday use. Problems with the inconsistent events approach indicate that a different

1. 103 S. Ct. 1134 (1983) (consolidated).

2. Id. at 1138 .

3. See, e.g., Blum, The Role of the Supreme Court in Federal Income Tax ControversiesHillsboro National Bank and Bliss Dairy, Inc., 61 TAXEs 363 (1983); Elliott, New test created for application of tax benefit rule as a result of Supreme Court decision, 11 TAX'N FOR LAW. 330 (1983); Feld, The Tax Benefit of Bliss, 62 B.U.L. REv. 443 (1982); O'Brien, Taxes on Bank Shares, 97 BANkING L.J. 845 (1980); O'Dell \& Boyd, The Tax Benefit Rule: The Supreme Court View, $9 \mathrm{~J}$. CoRP. L. 63 (1983); Schnee \& White, The tax benefit rule: the Supreme Court expands its scope, 14 TAX ADVISER 450 (1983); Scovanner, The tax benefit rule-the Supreme Court's interpretation, 14 TAX ADVISER 417 (1983); Yim, Supreme Court's tax benefit rule decision: Unanswered questions invite future litigation, $59 \mathrm{~J}$. TAX'N 130 (1983); Young, Bank Wins and Dairy Loses in Section 164(e) Tax Cases, 69 A.B.A. J. 822 (1983); Note, Formulation and Application of the Tax Benefit Rule: Hillsboro National Bank v. Commissioner, 37 Sw. L.J. 1009 (1984); Comment, The Tax Benefit Rule: Recovery Reevaluated, 36 U. MiAmI L. Rev. 533 (1982). 
solution to the difficulties inherent in the "recovery" tax benefit rule must be found. This Comment proposes a solution that encompasses inconsistent events as a concept, yet also provides a concrete rule of practical application. It is a solution that adds to the current tax benefit rule instead of redefining it. This solution is based on a common feature of the cases that have exposed a failure of the recovery approach. In each, the dispute centered around the disposition of an asset associated with previous deductions. Once the tax benefit problems inherent in the disposition of such an asset are solved, a coherent, practical "asset-based" approach einerges to compleinent the recovery tax benefit rule. For traditional wealth-enhancing events, the classic recovery approach is superior; for tax events based on a change in the character of an asset, a new asset-based model of the tax benefit rule is required.

Part I of this Comment recounts the history and operation of the tax benefit rule. It further explains the background of the Hillsboro and Bliss Dairy controversies. Part II summarizes the facts and the Supreme Court opinion in Hillsboro and Bliss Dairy, analyzes the operation of the inconsistent events approach, and concludes that the rule is vague and difficult to apply. Part III proposes an asset-based tax benefit rule, and contrasts it with the inconsistent events approach by applying both rules to commonplace transactions.

The History and Operation of the TAX Benefit Rule

\section{A. The Early Stages of the Tax Benefit Rule}

The tax benefit rule is a judicial doctrine that attempts to create parity among similarly situated taxpayers. ${ }^{4}$ The rule is necessary because of the interaction between two facets of the federal income tax systein. First, the system is based on annual accountimg, so that revenue is ascertainable and payable at regular intervals. ${ }^{5}$ This is necessary to inaintain a predictable and steady flow of tax dollars to the governinent. As a corollary, taxpayers report income and deductions based on facts known during the taxable year. ${ }^{6}$ The second facet of the tax sys-

4. See generally Bittker \& Kanner, The Tax Benefit Rule, 26 U.C.L.A. L. Rev. 265 (1978); Lassen, The Tax Benefit Rule and Related Problems, 20 TAXEs 473 (1942); O'Hare, Statutory Nonrecognition of Income and the Overriding Principle of the Tax Benefit Rule in the Taxation nf Corpo. rations and Shareholders, 27 TAX L. REv. 215 (1972); Plumb, The Tax Benefit Rule Tomorrow, 57 HARv. L. Rev. 675 (1944); Tye, The Tax Benefit Doctrine Reexamined, 3 TAX L. Rev. 329 (1948); White, An Essay on the Conceptual Foundations of the Tax Benefit Rule, $82 \mathrm{MicH}$. L. REv. 486 (1983).

5. Burnet v. Sanford \& Brooks Co., 282 U.S. 359 (1931).

6. Healy v. Commissioner, 345 U.S. 278 (1953); Lexmont Corp. v. Commissioner, 20 T.C. 
tem mandating the tax benefit rule is the system's income orientation. ${ }^{7}$ Thus, only the gains and income proceeding from capital are taxed; the capital itself remains untaxed. The tax benefit rule requires a taxpayer who recovers a previously deducted item or amount to report that item as mcome in the year of recovery, unless the previous deduction did not reduce her tax liability. ${ }^{8}$ This equalizes the treatment of such a taxpayer with one who had a recovery in the same year as the potential deduction, and consequently was never able to take the deduction. For example, if during the tax year the taxpayer lends funds and the debtor becomes insolvent, the taxpayer will not be allowed a bad debt deduction ${ }^{9}$ until the end of the tax year. If the debtor subsequently becomes solvent before the close of the tax year, the taxpayer's net position has not changed. No deduction is allowed, and repayment of the funds will not be taxable as incoune: it is a classic return of capital and beyond the reach of the federal imcome tax system. ${ }^{10}$ When the debtor repays the loan, only the excess over the principal (i.e., interest payments) will be taxed as income. If all of this occurs within one year, the aunual accounting system does not produce any distortion.

In contrast, a second taxpayer's transaction, identical in all respects except spanning two tax years, will produce a distortion. If the debt does not appear collectible at the end of the first year, the creditor may take a bad debt deduction and offset other income that would be subject to tax. ${ }^{11}$ However, if the debt is repaid during the second year and the taxpayer's claim that it is a return of capital succeeds in allowing it tax free, the second taxpayer will gain an advantage. Both taxpayers have received return of capital, but the second taxpayer receives an extra deduction. To combat such inequity, the courts developed the tax benefit rule. Although repayment of a previously uncollectable loan would normally be a return of capital, a require-

185 (1953); Treas. Reg. 1.461-1(a)(3)(i) (1967). However, when the final tax consequences of a transaction are not known, the annual accounting principle is mitigated. See, e.g., Burnet v. Logan, 283 U.S. 404 (1931) (gain or loss on sale of property contingent on.revenue from inherited contract; transaction left open and gain or loss determined when revenue received).

7. The 16th alnendment empowers Congress to tax "incomes, froun whatever source derived, without apportionment among the several States, and without regard to any census or enuneration." U.S. CoNST. amend. XVI. Incoune generally means a gain to the recipient. Thus, a return of the taxpayer's capital, which consists essentially of after-tax dollars, is not taxed twice. See Doyle v. Mitchell Bros. Co., 247 U.S. 179 (1918).

8. I.R.C. $\S 111$ (1982), amended by Deficit Reduction Act of 1984, Pub. L. No. 98-369, § 171(a), 1984 U.S. Code Cong. \& AD. News (98 Stat.) 494, 698.

9. See id. $\S 166$ (bad debts), amended by Deficit Reduction Act of 1984, Pub. L. No. 98-369, $\S 1001$ (b), 1984 U.S. Code Cong. \& AD. NEws (98 Stat.) 494, 1011.

10. Doyle v. Mitchell Bros. Co., 247 U.S. 179 (1918).

11. See I.R.C. § 166 (1982) (bad debts), amended by Deficit Reduction Act of 1984, Pub. L. No. 98-369, § 1001(b), 1984 U.S. CODE CoNG. \& AD. NEws (98 Stat.) 494, 1011. 
ment of mcome recogmition produces rough tax parity between similarly situated taxpayers. ${ }^{12}$

In its earhest formulation, the rule provided that if a taxpayer recovered a deduction she had previously taken, she would mclude the amount of the original deduction in income for the year of recovery. ${ }^{13}$ It soon became clear, however, that this simple construction of the rule could itself lead to inequities. Some taxpayers argued that although they had taken a deduction, the deduction had produced no tax benefit. $^{14}$ It was unfair to treat such a taxpayer identically with one for whom the deduction had offset income. In 1942, after a history of mconsistent positions taken by the Tax Court, the Commissioner, and the circuit courts, ${ }^{15}$ Congress enacted a statutory version of the tax benefit rule. This version excludes from income any recovery that did not produce a prior tax benefit. ${ }^{16}$

12. Such rough tax parity ignores the value of deferral of income taxes to the taxpayer who took a deduction in an earlier year, only to pay later. In that case, deferral amounts to an intcrestfree loan froin the government. This parity also disregards changes in brackets between years under a progressive rate system. Compare Perry v. United States, 160 F. Supp. 270 (Ct. Cl. 1958) (exact tax benefit rule), with Alice Plielan Sullivan Corp. v. United States, 381 F.2d 399 (Ct. Cl. 1967) (overruling Perry).

13. Lake View Trust \& Sav. Bank v. Coinmissioner, 27 B.T.A. 290, 292-93 (1932). A harshcr position was originally applied by the Internal Revenue Service, requiring inclusion in incoine if the original loss was deductible, even though not deducted. S.R. 2940, 4-1 C.B. 129 (1925). For a modern parallel to this approach, see I.R.C. $\$ 1016(a)(2)(1982)$, requiring a reduction in basis for depreciation "allowed or allowable" without regard to actual depreciation deductions. Under tax benefit situations involving recapture, this rule is initigated by allowing the taxpayer to prove that the amount allowed (that is, deducted) for any period was less than the amount allowable. See id. $\S 1245(\mathrm{a})(2)$.

14. This approach was initially accepted by the Commissioner for banks with bad debt deductions, G.C.M. 18525, 1937-1 C.B. 80 , and quickly extended to other taxpayers, G.C.M. 20854, 1939-1 C.B. 102, and tax benefit situations beyond bad debt recoveries, I.T. 3728, 1939-1 C.B. 76 (tax refunds).

15. In 1940, the Commissioner prospectively revoked and modified prior tax benefit rule revenue rulings, and returned to his original position that recoveries are taxable regardless of any tax benefit produced by the prior deduction. G.C.M. 22163, 1940-2 C.B. 76 (declared obsolete by Rev. Rul. 67-406, 1967-2 C.B. 420). This position was upheld by the circuit courts, Counnissioner v. United States \& Int'l Sec. Corp., 130 F.2d 894 (3d Cir. 1942); Helvering v. State-Planters Bank \& Trust Co., 130 F.2d 44 (4th Cir. 1942), thus producing a conflict with the Board of Tax Appeals. See, e.g., Citizens State Bank v. Commissioner, 46 B.T.A. 964 (1942). For an exhaustive presentation of the history of the tax benefit rule, see Plumb, The Tax Benefit Rule Today, 57 HARv. L. REV. 129, 130-34, 134-50 (1943).

16. Revenue Act of 1942 , clr. 619, $\S 116,56$ Stat. 798, 812-13 (codified at I.R.C. $\S 22$ (b)(12) (1952) (1939 Code)) (current version at I.R.C. $\$ 111$ (1982), amended by Deficit Reduction Act of 1984, Pub. L. No. 98-369, § 171(a), 1984 U.S. Code Cong. \& AD. News (98 Stat.) 494, 698). The legislative history of this section reveals that Congress recognized the confusion surrounding the tax benefit rule and attenipted to resolve it with the enactment of $\$ 22(\mathrm{~b})(12)$. See H.R. REP. No. 2333, 77th Cong., 2d Sess. 69-71 (1942); Bittker \& Kanner, supra note 4, at 277-81; Pluinb, supra note 15, at 151-71; Tye, supra note 4.

I.R.C. $\$ 111$ (1982), amended by Deficit Reduction Act of 1984, Pub. L. No. 98-369, § 171(a), 1984 U.S. CoDE CoNG. \& AD. NEws (98 Stat.) 494, 698, the current version under the lnternal 
The statutory rule, as authoritatively construed by Congress and later by the Supreme Court, ${ }^{17}$ had three requirements: a prior deduction; a tax benefit from that deduction; and a recovery of the deduction. Furthermore, it was not an exclusive rule, ${ }^{18}$ and courts were free to apply a tax benefit theory beyond the precise terms of the statute. ${ }^{19}$ With this expanded interpretation, the controversy over the tax benefit rule seemed settled. But the recovery requirement was to produce great theoretical and practical obstacles.

\section{B. The Problem with "Recovery"}

Under the classic tax benefit rule, a recovery was necessary to trigger a recognition of income. In Commissioner v. South Lake Farms, Inc. ${ }^{20}$ a dispute arose following one corporation's acquisition and liquidation of another. The taxpayer in question was the target corporation, which was engaged im the busmess of farming and was operating under the accrual method of accounting. After it had spent and accrued considerable deductible sums on the cultivation of crops, but before harvest, its shareholders sold it to the purchasing corporation. Naturally, the price paid to the target corporation's shareholders reflected the fair market value of the growing crops. And, the purchaser's basis in the target corporation's stock was its cost-the fair market

Revenue Code of 1954 , is substantially unchanged from the 1939 version, I.R.C. $\S 22(b)(12)$ (1952).

17. Dobson v. Commissioner, 320 U.S. 489 (1943).

18. Id.

19. I.R.C. $\S 111$ (1982), amended by Deficit Reduction Act of 1984, Pub. L. No، 98-369, $\S 171$ (a), 1984 U.S. CODE CoNG. \& AD. NEws (98 Stat.) 494, 698, addresses only "bad debts, prior taxes, and delinquency amounts." After Dobson v. Commissioner, 320 U.S. 489 (1943), the Commissioner responded with T.D. 5454, 1945 C.B. 68 , holding that the tax benefit rule applies to all losses, expenditures, and accruals made on the basis of deductions im prior years. The regulations also reflect this position. See Treas. Reg. $\S 1.111-1$ (a) (1956). As a result the rule has been applied to several situations, imcluding: (1) repayments following casualty losses, Montgomery v. Commissioner, 65 T.C. 511 (1975) (imsurance proceeds on casualty loss); Mager v. United States, 19801 U.S. Tax Cas. (CCH) I 9236 (M.D. Pa.) (condemnation award is a recovery of prior casualty loss on property), affd per curiam, 636 F.2d 1209 (3d Cir. 1980); Rev. Rul. 71-160, 1971-1 C.B. 75 (forgiveness of disaster rehef loans is a recovery of prior casualty losses); (2) losses on sales of capital assets later recovered, Dobson v. Commissioner, 320 U.S. 489 (1943); United States v. Rexach, 482 F.2d 10 (1st Cir.), cert. denied, 414 U.S. 1039 (1973); (3) cancellation of accrued liabilities already deducted by the debtor, Roxy Custom Clothes Corp. v. United States, 171 F. Supp. 851 (Ct. Cl. 1959); G.M. Standifer Constr. Corp. v. Commissioner, 30 B.T.A. 184 (1934), appeal dismissed, 78 F.2d 285 (9th Cir. 1935); see also Larchfield Corp. v. United States, 373 F.2d 159 (2d Cir. 1966) (restoration of excessive bonuses to corporation by majority shareliolder); but cf. Putoma Corp. v. Commissioner, 66 T.C. 652 (1976) (forgiveness of accrued interest owed to shareholders deemed imcome), affd, 601 F.2d 734 (5th Cir. 1979); and (4) recoveries of property from charitable organizations, Rosen v. Commissioner, 611 F.2d 942 (1st Cir. 1980); Alice Phelan Sullivan Corp. v. Umited States, 381 F.2d 399 (Ct. Cl. 1967); Rev. Rul. 76-150, 1976-1 C.B. 38.

20. 324 F.2d 837 (9th Cir. 1963). 
value of the target. ${ }^{21}$ Immediately after the purchase, the buyer liquidated the target corporation, and received, among other assets, the unharvested crops. Under section 334(b)(2) of the Internal Revenue Code (the "Code"), the purchaser allocated its basis in the stock of the target to the assets of the target it received in liquidation ${ }^{22}$ according to the assets' fair market values. ${ }^{23}$ When the crops were liarvested by the purchaser, it deducted the fair market value of the crops from their basis and realized little gain. ${ }^{24}$

The Commissioner, lowever, mcluded the fair market value of the crops in the target's last tax return, asserting that the target's method of accounting distorted income. The Tax Court rejected this theory, ${ }^{25}$ and on appeal the Commissioner was forced to rely on a tax benefit argument. He asserted that im effect the target had received "an ainount equivalent to, and sufficient to offset, the expenses that it had incurred, and hence was no longer entitled to the 'tax benefit' of the deduction of [the] expenses."26 This argument presumably relied on imputing the receipt of the purchase price by the shareholders to the target corporation.

The Ninth Circuit was unconvinced. The appellate panel noted that the tax benefit theory failed, in part because the corporation's shareholders received the money and the corporation received nothing. ${ }^{27}$ Since the corporation did not have the required recovery, the court considered itself bound by the literal language of the Code. Even though the shareliolders of the target received a windfall, ${ }^{28}$ nothing in

21. See I.R.C. $\$ 1012$ (1982) (basis of property shall be cost).

22. The transaction was treated as a purchase of assets under the Kimbell-Diamond doctrine. See Kimbell-Diamond Milling v. Commissioner, 14 T.C. 74 (1950), aff'd per curiam, 187 F.2d 718 (5th Cir.), cert. denied, 342 U.S. 827 (1951); I.R.C. § 334(b)(2) (1982), amended by Tax Equity and Fiscal Responsibility Act of 1982, Pub. L. No. 97-248, § 224(b), 96 Stat. 480, 488-89.

23. Under I.R.C. § 334(b)(2) (1982), amended by Tax Equity and Fiscal Responsibility Act of 1982, § 224(b), Pub. L. No. 97-248, 96 Stat. 324, 488-89, the basis of the assets received in the liquidation of a subsidiary is the parent's basis in the subsidiary's stock. Treas. Reg. \$1.334-1(c) (1972) requires a parent corporation to allocate its basis in the stock of the liquidated subsidiary to the assets received in the liquidation. Treas. Reg. $\$ 1.334-1$ (c)(4)(viii) (1972) requires this allocation to be inade "in proportion to the net fair market values of sucl assets on the date received."

24. South Lake Farms, 324 F.2d at 844 (Carter, J., dissenting).

25. South Lake Farms, Inc. v. Commissioner, 36 T.C. 1027 (1961).

26. South Lake Farms, 324 F.2d at 839. The court responded that "[o]ne immediate difficulty with this contention is that the old corporation received nothing." Id.

27. See supra note 26.

28. A windfall exists because the purcliaser acquired the target corporation's stock, not its assets. Had it acquired the assets, the target corporation would have lad to pay taxes on the gain associated with the sale of those assets. See I.R.C. \&337(b)(1)(A) (1982). If the target corporation then liquidated, the shareholders would lrave received the value of the assets, less the tax liability. However, since the purcliaser bought the stock of the target directly, the shareholders received the fair inarket value of the corporation's assets, without the corresponding tax liability deducted. The purcliaser was willing to pay up to full fair market value for the target because when the 
the Code called for a different result. ${ }^{29}$

The Sixth Circuit saw the recovery requirement of the tax benefit rule in a different light. In Tennessee-Carolina Transportation, Inc. $v$. Commissioner, ${ }^{30}$ the parent liquidated a subsidiary by returning all the subsidiary's stock to it in return for the subsidiary's assets. Among the assets the parent received were certain supplies of the subsidiary, the cost of which had been deducted. In the same method as the South Lake Farms transaction, the parent allocated its basis in the subsidiary's stock to the assets received according to their fair market values. Since some of the assets so received were supplies, the parent then deducted the allocated basis as a busmess expense. ${ }^{31}$

The Commissioner contended that the tax benefit rule required the value of these assets to be included in the imcome of the subsidiary, and the Sixth Circuit agreed. If the tax benefit rule did not apply to in-kind hquidations, the court ruled, there would be unnecessary disparity in the Code: ${ }^{32}$ had the liquidation proceeded under the nonrecognition provisions of section 337 (relating to hquidation sales), the tax benefit rule would have required income recogmition notwithstanding that section's nonrecognition inandate..$^{33}$

The taxpayer argued that there was no recovery to trigger the tax benefit rule, but the appellate court rejected this argument for three reasons. First, a recovery should not be necessary; the tax benefit rule applies "whenever there is an actual recovery of a previously deducted amount or when there is solne other event inconsistent with that prior - deduction." 34 The distribution of the supphes in liquidation was inconsistent with the previous deduction of their cost, and thus the rule was triggered. ${ }^{35}$ Second, even if a recovery was necessary under the tax benefit rule, a recovery occurred when the subsidiary liquidated. When the supplies were expensed, they were treated under the tax law as coinpletely consuined and nonexistent. Therefore, when the subsidiary had the supplies on hand to distribute at hquidation, it must be deeined to have recovered them, which triggered the tax benefit rule. ${ }^{36} \mathrm{Third}$, the subsidiary's receipt of its own stock in exchange for its assets consti-

purchaser subsequently liquidated the target, there was no taxable event, hence no tax liability. The purchaser inerely allocated its basis in the stock of the now-liquidated target to the assets received in liquidation.

29. South Lake Farms, 324 F.2d at 840.

30. 582 F.2d 378 (6th Cir. 1978), cert. denied, 440 U.S. 909 (1979).

31. Id. at $379-80$.

32. Id. at 381 .

33. See, e.g., Spitalny v. United States, 430 F.2d 195 (9th Cir. 1970); Commissioner v. Anders, 414 F.2d 1283 (10th Cir.), cert. denied, 396 U.S. 958 (1969); Anders v. United States, 462 F.2d 1147 (Ct. Cl. 1972); Estate of Munter v. Commissioner, 63 T.C. 663 (1975).

34. Tennessee-Carolina, $582 \mathrm{~F} .2 \mathrm{~d}$ at 382 (emphasis in origimal).

35. Id.

36. Id. 
tuted a recovery within the meaning of the tax benefit rule. ${ }^{37}$

Thus, a conflict existed among the circuits as to whether a recovery was necessary to trigger the tax benefit rule. ${ }^{38}$ This conflict impaired the predictability, and thus the usefuhress, of the rule, and remained until the Supreme Court decided the Hillsboro and Bliss Dairy cases.

II

The Cases

\section{A. Hillsboro National Bank v. Commissioner}

On January 1, 1971, Illinois amended its constitution to prohibit ad valorem taxation of property held by individuals. ${ }^{39}$ Later that year, the Illinois Supreme Court mvahiated the amendment, ${ }^{40}$ ruling that it violated the equal protection clause of the Uinted States Constitution. Pendimg disposition of the case before the United States Supreme Court, Illinois enacted legislation providing for placement of the dis-

37. Id.

38. Compare Ballou Constr. Co. v. United States, 526 F. Supp. 403 (D. Kan. 1981) (no "recovery" found, therefore no application of tax benefit rule), vacated, 706 F.2d 301 (10th Cir. 1983), with Bonaire Dev. Co. v. Commissioner, 76 T.C. 789 (1981) (no recovery requirement), affd on other grounds, 679 F.2d 159 (9th Cir. 1982). See generally Bittker \& Kanner, supra note 4; Bonovitz, Problems in Achieving Parity in Tax Treatment Under Sections 337 and 334(b)(2), 34 N.Y.U. INST. FED. TAX'N 57 (1976); Broenen, The Tax Benefit Rule and Sections 332, 334(b)(2) and 336, 53 TAXES 231 (1975); Byrne, The Tax Benefit Rule as Applied to Corporate Liquidations and Contributions to Capital: Recent Developments, 56 Notre DAME LAW. 215 (1980); Diller, Corporate Liquidations and the Tax Benefit Rule: A Search for the "Recovery" Element, 9 OHIO N.U.L. REV. 257 (1982); Epstein, The tax benefit rule in corporate liquidations, 6 TAX ADvisER 454 (1975); Forte, Corporate Liquidations-Sections 336 and 337 of the Internal Revenue Code-Parity Between a Direct Sale of Assets and a Stock Purchase-Another Look at Tennessee-Carolina and R.M. Smith, 3 W. NEW ENG. L. REv. 199 (1980); Gutkin \& Beck, Section 337: IRS wrong in raxing, at time of liquidation, items previously deducted, $17 \mathrm{~J}$. TAX'N 146 (1962); Johnson, The Tax Benefit Rule-Overexpansion in Liquidation Situation, 22 S. TEx. L.J. 331 (1982); Morrison, Assignment of Income and Tax Benefit Principles in Corporate Liquidations, 54 TAXES 902 (1976); Reveley \& Pratt, Tax Benefit Rule: What Constitutes a Recovery? Sixth and Ninth Circuits Disagree, 57 TAXES 416 (1979); Shaw, The Application of the Tax Benefit Rule to Corporate Distributions of Expensed Assets Under I.R.C. Section 336, 29 CASE W. Res. L. Rev. 700 (1979); Note, The Tax Benefit Rule and Corporate Liquidations: Baiting the "Trap for the Unwary", 4 J. CoRP. L. 681 (1979); Note, Tax Treatment of Previously Expensed Assets in Corporate Liquidations, 80 MicH. L. REv. 1636 (1982) [hereinafter cited as Note, Previously Expensed Assets]; Note, The Tax Benefit Rule, Claim of Right Restorations, and Annual Accounting: A Cure for the Inconsistencies, 21 VAND. L. REV. 995 (1968); Note, The Tax Benefit, Recoveries, and Sales of Property Under Section 337, 9 WM. \& MARY L. REV. 476 (1967).

39. Article IX-A of the Illinois Constitution of 1870 amended the Illimois Constitution to abolish the ad valorem taxation of personal property held by individuals, effective January 1 , 1971. ILL. ConsT. OF 1870, art. IX-A, $\$ 1$ (1970). Illinois anticipated this change in the 1870 constitntion and incorporated it in article IX of a new constitution effective July 1, 1971, which provides "[a]ny ad valorem personal property tax abolislied on or before the effective date of this Constitution sluall not be reinstated." ILL. CoNST. OF 1970, art. IX, § 5(b).

40. Lake Shore Auto Parts Co. v. Korzen, 49 Ill. 2d 137, 151, 273 N.E.2d 592, 599 (1971), rev'd sub nom. Lehnhausen v. Lake Shore Auto Parts Co., 410 U.S. 356 (1973). 
puted property taxes in escrow. ${ }^{41}$ Under this statutory scheine, Hillsboro National Bank paid approximately $\$ 26,000$ in property taxes assessed upon its individual shareholders' corporate interests, and deducted thein on its 1972 incoine tax return. ${ }^{42}$ Although shareholders are personally hable for the taxes, it is common for corporations to pay thein and take a deduction pursuant to section 164(e) of the Code. ${ }^{43}$

In 1973, the United States Supreme Court found the ainendinent constitutional, reversing the determination of the Illinois Supreine Court. ${ }^{44}$ The state then refunded the taxes directly to the individual shareholders, ${ }^{45}$ without consulting the bank. ${ }^{46}$ The bank reported no incoine froin these transactions on its 1973 tax return, and the Commissioner of Internal Revenue assessed a $\$ 13,000$ deficiency. ${ }^{47}$ Hillsboro objected and petitioned the Tax Court for relief.

Hillsboro argued for a straightforward apphication of the classic definition of the tax benefit rule: since it never received any of the refunded taxes, it had no "recovery," and thus fell outside the rule. The Commissioner's response was two pronged. The bank derived a benefit fron the refunds because they discharged its duty to treat all shareholders of the saine class equally when paying out dividends. ${ }^{48}$ Furthermore, the bank constructively received the refunds by failing to pursue its rightful claim to them, and thereafter "paid" the refunds to its individual shareholders. ${ }^{49}$

The Tax Court, agreeing with the Commissioner, rehed on its prior ruling in Tennessee Carolina Transportation, Inc. v. Commissioner, ${ }^{50}$ and found that a recovery was not necessary. ${ }^{51}$ Alternatively, the court found that even if a recovery were required, the facts could be

41. Public Act 77-2133, 1972 Ill. Laws 942, repealed by Public Act 81-1, 1st Spec. Sess., § 11, 1979 Ill. Laws 4959 (repeal effective December 31, 1982).

42. Hillsboro Nat'l Bank v. Commissioner, 73 T.C. 61, 62 (1979).

43. I.R.C. \& 164(e) (1982) provides:

Where a corporation pays a tax imposed on a sharelolder on his interest as a shareloolder, and where the shareholder does not reinburse the corporation, then-

(1) the deduction allowed by subsection (a) [for such tax] sliall be allowed to the corpora-

tion; and

(2) no deduction shall be allowed the shareholder for such tax.

44. Lehnhausen v. Lake Shore Auto Parts Co., 410 U.S. 356 (1973).

45. Hillsboro, 73 T.C. at 64.

46. Id:; cf. First Trust \& Sav. Bank v. United States, 44 A.F.T.R.2d (P-H) I 79-5253 (C.D. Ill. 1979), affd, 614 F.2d 1142 (7th Cir. 1980).

47. Hillsboro, 73 T.C. at 61 .

48. The ad valorem tax was only repealed for individuals; thus corporate shareliolders received no refund. See supra note 39.

49. Hillsboro, 73 T.C. at 66.

50. 582 F.2d 378 (6tl Cir. 1978), cert. denied, 440 U.S. 909 (1979); see supra text accompanying notes 30-37.

51. Hillsboro, 73 T.C. at 68. 
construed to indicate one. ${ }^{52}$ "[T] he transfer of petitioner's erstwhile tax payment to its shareholders belies the assumption under which the original deduction was allowed, i.e., that petitioner was paying a State property tax." 53 For the benefit to pass to the shareholders, the bank "must first be deemed to have recovered its payments." Although the court admitted it was imdulging a fiction in finding a recovery, it held its prior ruling in Tennessee Carolina controlling. ${ }^{54}$

On appeal, the Seventh Circuit lield the case to be controlled by First Trust and Savings Bank $v$. United States. ${ }^{55}$ The facts im that case were similar to those in Hillsboro, except that the refund checks had been payable to the bank and the shareholders jointly. The Seventh Circuit affirmed the district court's alternative findings in First Trust that the bank liad recovered the refunds and that an actual recovery is not required to invoke the tax benefit rule. ${ }^{56}$ Thus, im Hillsboro, application of the tax benefit rule could be justified on two grounds: "an actual recovery of a previously deducted amount or some other event inconsistent with that prior deduction." ${ }^{37}$ The refund to the bank's shareholders was both a recovery and an event inconsistent with the prior deduction. That inconsistent event changed the tax payments from a deductible expense for the bank imto a nondeductible dividend. ${ }^{58}$

\section{B. United States v. Bhiss Dairy}

During the 1972-73 fiscal year, Bliss Dairy, a farming corporation, deducted $\$ 150,000$ it had paid for cattle feed as a busmess expense. On the second day of its next fiscal year, the corporation adopted a plan of liquidation. It distributed its assets, among whicl was remaining cattle feed valued at $\$ 56,000$, to its shareholders who contmued to operate the business in noncorporate form. ${ }^{59}$ They computed their basis in the assets under section 334(c) of the Code, ${ }^{60}$ and claimed a business expense deduction on their 1973 individual income tax returns to the extent of their basis in the feed.

52. Id. at 67-68.

53. Id. at 68 .

54. Id.

55. 614 F.2d 1142 (7th Cir. 1980).

56. Id. at 1146.

57. Hillsboro Nat'l Bank v. Commissioner, 641 F.2d 529, 531 (7th Cir. 1981), rev'd, 103 S. Ct. 1134 (1983) (emphasis in original).

58. Id.

59. Bliss Dairy, Inc. v. United States, 645 F.2d 19, 19-20 (9th Cir. 1981) (per curiam), rev'd, 103 S. Ct. 1134 (1983).

60. I.R.C. $\S 334$ (c) (1982) provides that if a shareholder in a corporate liquidation acquires property and, under I.R.C. $\$ 333$ (1982), she does not recognize gain, then the property retains the same basis as the shareholder's stock. 
The Commissioner determined a deficiency in the corporation's last income tax return based on the corporation's distribution of the previously expensed grain. The corporation's gross income was increased by the value of the gram, and it paid the resulting tax. It then sued for a refund and won a summary judgment in the district court. Although the Ninth Circuit recognized the conflict among the circuits regarding the recovery requirement, it affirmed, relymg on its decision in South Lake Farms. ${ }^{61}$

\section{The Supreme Court Decision}

The Supreme Court granted certiorari in both cases and consolidated thein for opinion. The majority focused on the problems created by the annual accounting system, transactions that span many years, and events in later years that may or may not constitute a recovery. The Court noted that the recovery requirement of the traditional tax benefit rule complicates the argument without adding to the analysis of the substantive issues at hand. ${ }^{62}$

The Court found that the rule's object is to approximate transactional accounting. To achieve this goal, the rule should come into play "only when a careful exammation shows that the later event [triggermg the rule] is indeed fundamentally inconsistent with the premise on which the [prior] deduction was initially based. That is, if that event had occurred within the same taxable year, it would have foreclosed the deduction." ${ }^{\prime 3}$ The Court reasoned that this interpretation of the rule was consistent with the rule's long history, and the Court's prior tax benefit rulings. ${ }^{64}$

The Court then proceeded to apply its new "mconsistent events" analysis to the facts of Hillsboro. Section 164(e), under which the bank had taken a deduction, essentially gives shareholders a dividend deductible to the corporation, as the corporation is paying a portion of the shareholder's tax hability and is permitted to take a deduction for the amount paid. The Commissioner in Hillsboro found the shareholders'

61. Bliss Dairy, 645 F.2d at 20.

62. Hillsboro Nat'l Bank v. Commissioner, 103 S. Ct. 1134, 1142-43 (1983).

63. Id. at 1143-44 (footnote omitted).

64. In Nash v. Umited States, 398 U.S. 1 (1970), a partnership mcorporated and transferred accounts receivable to the newly formed corporation subject to a bad debt reserve. The Service argued that the tax benefit rule required inclusion in income of the unused reserve. However, the Court refused to construe the end of need as a recovery. The fair market value of the receivables equaled the face amount less the bad debt reserve. Id. at 4 . The reserve, according to the Hillsboro Court, was still an accurate measure of debts that would eventually be uncollectable. Therefore, the deduction was completely consistent with a later transfer of the receivables. Hillsboro, 103 S. Ct. at 1147; see infra note 170. The only other tax benefit rule case the Supreme Court has taken is Dobson v. Commissioner, 320 U.S. 489 (1943). The rule was referred to indirectly in United States v. Skelly Oil Co., 394 U.S. 678 (1969); see Hillsboro, 103 S. Ct. at 1158 n.18. 
receipt of cash to be inconsistent with the bank's prior deduction, and assessed a deficiency. But the Court noted that the Code contemplated a deductible dividend in these circunstances. ${ }^{65}$ Thus, the question involved the transmutation of the character of the taxes:

The question we must answer is whether $\S 164(\mathrm{e})$ permits a deductible dividend in these circumstances-when, the money, though initially paid into the state treasury, ultimately reaches the shareholder-or whether the deductible dividend is available, as the Commissioner urges, only when the money remains in the state treasury, as properly assessed and collected tax revenue. ${ }^{66}$

To answer this question, the Court looked to the legislative history of section 164(e). The only enlightening statements about this provision were made by a Senator who noted that banks commonly pay these taxes. ${ }^{67}$ Since Congress thus appeared to be allowing a deduction because the corporation was paying, the Court concluded that the state's action in turning over the tax revenues to third parties had no bearing on the deduction. "[T]he focus of Congress was on the act of payment rather than on the uitimate use of the funds by the state."68 As long as the actual payinent was not negated by a refund to the payor, the transmutation of the funds by the state did not trigger the tax benefit rule, ${ }^{69}$ as it was not an inconsistent event. Thus, the bank escaped taxation.

In Bliss Dairy, the corporation had deducted the cost of grain as a business expense ${ }^{70}$ and then distributed the grain to its shareholders im hiquidation. The Court ruled that a conversion of an expensed asset to a nonbusiness use is inconsistent with a prior business expense deduction, and the tax benefit rule applies:

That non-busmess use is inconsistent with a deduction for an ordinary and necessary business expense is clear from an examination of the Code. . . . Thus, if a corporation turns expensed assets to the analog of personal consumption, as Bhss did here-distribution to shareholders-it would seem that it should take into incoine the annount of the earher deduction. ${ }^{71}$

However, the analysis in this case was comphicated by the apphica-

\section{Hillsboro, $103 \mathrm{~S} . \mathrm{Ct}$. at 1148.}

66. $I d$.

67. Id. at 1149 (quoting Hearings on H.R. 8245 Before the Comm. on Finance, 67th Cong., 1st Sess. 251 (1921) (statement of Sen. Smoot)) (emphasis added by the Court):

I have been a director of a bank . . . for over 20 years. They have paid that tax ever since I have owned a share of stock in the bank. . . . I know nothing about it. I do not take 1 cent of credit for dcductions, and the banks are entitled to it. They pay it out.

68. $I d$.

69. Id.

70. See Treas. Reg. $\$ 1.162-3$ (1960).

71. $103 \mathrm{~S}$. Ct. at 1150 (emphasis added) (footnotes omitted). 
bility of a nonrecognition provision-section $336 .{ }^{72}$ The tax benefit rule should not operate to produce inconre if the nonrecognition policies at stake override the policies behind the rule. To resolve this balance in Bliss Dairy, the Court closely examined section 336. First, the Court noted that Congress enacted section 336 as a codification of the General Utilities ${ }^{73}$ doctrine: a corporation recognizes no gain on the distribution of appreciated property to its shareholders. The real concern behind this doctrine was to shield nrarket appreciation, as opposed to ordinary income. ${ }^{74} \mathrm{So}$, for exainple, when a corporation attenipts to distribute an asset normally giving rise to ordinary inconie, the nonrecognition nrandate of section 336 yields to Code principles prohibiting assignment of income and providing for recapture under sections 1245 and $1250 . .^{75}$

To determine the relation of section 336 to the tax benefit rule, the Court looked to a conipanion provision, section 337, which covers hquidating sales. These sections inust be analyzed together for two reasons. First, the language of the two sections is inarkedly similar. Second, the legislative history of section 337 reveals that it was codified to prevent formalistic distinctions between hquidations preceded by a sale of assets and liquidations in kind (e.g., those covered by section 336). Thus, "[t]he very purpose of $\S 337$ was to create the same consequences as $\S 336 . " 76$

The Court noted that courts have long apphed the tax benefit rule to section 337 liquidations, and Congress has not interfered. ${ }^{77}$ In addition, the exceptions to section 337 governing treatment of inventory indicate that Congress did not intend to shield ordinary business inconie. The Court in Bliss Dairy therefore concluded that section 336 does not shield a liquidating corporation from the tax benefit rule, and the dairy thus had to include the prior deduction in inconie. The proper inclusion was the portion of the original cost of the grain attributable to the aniount distributed to the shareholders on hiquidation. ${ }^{78}$

72. Section 336 provides, with some exceptions, that a corporation shall recognize no gain or loss on the distribntion of property in complete liqnidation.

73. General Utils. \& Operating Co. v. Helvering, 296 U.S. 200 (1935).

74. 103 S. Ct. at 1151-52; see S. REP. No. 1622, 83d Cong., 2d Sess. 258, reprinted in 1954 U.S. Code CONG. \& AD. News 4621; H.R. REP. No. 1337, 83d Cong., 2d Sess. at A90, reprinted in 1954 U.S. CODE CONG. \& AD. News 4017, 4062-63.

75. 103 S. Ct. at 1151; see Siegel v. United States, 464 F.2d 891 (9th Cir. 1972), cert. dismissed, 410 U.S. 918 (1973); Williamson v. United States, 292 F.2d 524 (Ct. Cl. 1961).

76. Hillsboro, $103 \mathrm{~S} . \mathrm{Ct}$. at 1152.

77. See Lorillard, Inc. v. Pons, 434 U.S. 575 (1978).

78. Hillsboro, 103 S. Ct. at 1153-54. Justice Stevens, joined by Justice Marshall, concurred in Hillsboro and dissented in Bliss Dairy. Justice Stevens objected to the significant enlargennent of the tax benefit rule and the conconitant expansion of the Commissioner's powers. Id. at 1154 (Stevens, J., concurring and dissenting). Justice Blackmun dissented separately, proposing that 


\section{The Hillsboro Inconsistent Events Rule}

The Hillsboro approach essentially requires a two-step analysis. First, a court must search for an event that is inconsistent with the prior deduction. If such an event is found, the second step requires a search for a conflicting nonrecognition provision. If a nonrecognition provision applies, the court must balance it agamst the tax benefit rule to determine whether the tax benefit rule prevails.

Unfortunately, the scope of this approacli is difficult to gauge. One of the most troubling difficulties with the Hillsboro rule is the lack of a clear definition of the term "mconsistent event." The Court emphasized that "only if the occurrence of the event in the earlier year would liave resulted in the disallowance of the deduction can the Commissioner require a compensating recognition of income when the event occurs in the later year."79 This language can be interpreted in two ways. The Court may liave intended it as an exclusive definition of a fundamentally inconsistent event. ${ }^{80}$ Thus, an event that seems theoretically mconsistent but that would not liave led to the disallowance of the deduction liad it occurred in the prior year would not fall within this exclusive definition. On the other hand, the Court may have intended the quoted language to provide only an example of an inconsistent event. Even events that would not have led to a disallowance of the deduction could be inconsistent. Under this broader notion of an inconsistent event, the theory of the deduction must be exainined in

the Commissioner reopen the tax returns of the year in which the deduction was taken, assuming the statute of limitations had not expired. Id. at 1166 (Blackmun, J., dissenting).

79. Id. at 1146 (emphasis in original).

80. In order to determine which events are fundamentally inconsistent with the original deduction, it is first necessary to define the terms "fundamental" and "imconsistent." For example, in Hillsboro the Sohicitor General argued that the inconsistent events theory required the bank to recognize income because the repeal itself would be inconsistent with a deduction taken for payment of the tax as soon as the tax was repealed. Respondent's Oral Argument at 33:8-15, Hillsboro Nat'l Bank v. Commissioner, 103 S. Ct. 1134 (1983) (on file with the California Law Review). Under this argument, the tax benefit rule would have been triggered even if the state had refused to refund the taxes, as the bank would still have had a claim to the taxes. Id.

A claim is not enough to produce income, however. For example, a taxpayer may take a bad debt deduction when the debt is deemed uncollectible and when legal action to enforce payment would not in all probabihty result in satisfaction. Treas. Reg. $\$ 1.166-2$ (b) (1973). The taxpayer will only have imcome upon recovery. I.R.C. \& III (1982) (presumably preempting the tax benefit rule in such an area), amended by Deficit Reduction Act of 1984, Pub. L. No. 98-369, § 171(a), 1984 U.S. Code CoNG. \& AD. News (98 Stat.) 494, 698-99; see also Treas. Reg. § 1.166-1(f) (1983). Furthermore, even if the refund checks had been stolen before they reached the sharcholder, the bank would still have realized income through repeal of the tax under the Solicitor General's theory. Respondent's Oral Argument at 35:25; 36:4, Hillsboro Nat'l Bank v. Commissioner, 103 S. Ct. 1134 (1983) (on file with the California Law Review).

While repeal of the tax may thus be imconsistent, it may not be fundamentally inconsistent. The Court, however, fails to define "fundamental" inconsistencies further, except to state that the triggering event is one that is fundamentally imconsistent with the premise upon which the original deduction was based. Hillsboro, $103 \mathrm{~S}$. Ct. at 1143. See Blum, supra note 3, at 366. 
light of subsequent events to determine whether a fundamental inconsistency exists with respect to a general premise of the tax system.

\section{Disallowance of Prior Deductions as an Exclusive Definition}

The Hillsboro opinion twice noted that an occurrence that would have caused the prior deduction to be disallowed is an inconsistent event. This is persuasive evidence for the view that the Court meant to establish an exclusive definition of that term. This imterpretation is mitially attractive, as it provides an ostensibly clear-cut boundary for the tax benefit rule. However, as with many rules in the field of taxation, it also raises unanticipated complexities. Indeed, the deduction disallowance theory provides even less guidance to the taxpayer than the original recovery requirement. This confusion is particularly acute when the rule is applied to a hquidating corporation that is distributing expensed assets to its shareholders.

In Bliss Dairy, for example, the corporation expensed cattle feed under section 162 of the Code. Under the Hillsboro test, the Court had to determine whether the dairy's subsequent liquidation and distribution of the grain to the stockholders would have led to a disallowance of the original expensing deduction had it all occurred in the same year. In its resolution of this question, the Court stated that "[i]n general, if the taxpayer converts the expensed asset to some other, nonbusmess use, that action is inconsistent with his earlier deduction, and the tax benefit rule would require inclusion in income of the amount of the unwarranted deduction." $" 81$

In reaching this conclusion, the Court ignored the very analysis that would have indicated whether such an event is indeed inconsistent. Instead, it summarily asserted that distribution to the shareholders is a nonbusiness use-cthe analog of personal consumption." 82 Although it is clear that personal expenses, being nondeductible, ${ }^{83}$ and business expenses, deductible under section 162, are incompatible, it is not at all clear that the distribution in a liquidation is akin to personal consumption. The required analysis should involve an exammation of the deduction, the subsequent event, and statutory and judicial treatments of similar deduction disallowances.

For example, the facts in Bliss Dairy can be likened to other deduction disallowance situations that courts liave faced, including subsequent liquidation sales and conversions. Although a subsequent sale may be a similar deduction disallowance transaction, analogizing liquidations to sales provides hittle guidance. It has long been recognized

81. Hillsboro, $103 \mathrm{~S}$. Ct. at 1150.

82. Id.

83. I.R.C. $§ 262$ (1982). 
that the tax benefit rule applies to the sale of expensed assets in a hiquidation. $^{84}$ In Spitalny $v$. United States, ${ }^{85}$ the Ninth Circuit was faced with a liquidation and sale of assets expensed in the same year. Both at trial and on appeal, the government asserted that it had disallowed the expense to prevent income distortion. ${ }^{86}$ The Ninth Circuit held that the government was actually relying on the tax benefit rule, and not challenging the propriety of the deduction. While it agreed that the tax benefit rule was inapposite because all the events took place within a single tax year, the court emphasized that the principles of the rule applied to hquidating sales. ${ }^{87}$ However, this decision was not a true tax benefit rule case and, coming before Hillsboro, it offers no insight into application of the inconsistent events approach to such situations.

Expensing an asset can also be likened to instantaneous depreciation. The status of a depreciation deduction in a liquidation year, however, depends on the type of depreciation involved. While section 167 depreciation is allowed in the year of disposition, ${ }^{88}$ accelerated cost recovery (ACRS) is not. ${ }^{89}$ Since ACRS is usually the faster depreciation method, it is most analogous to immediate expensimg.

Nevertheless, the pecuharities of depreciation limit its similarities to expensing. On a theoretical level, there is a fundamental difference between expensing and depreciation. Expensmg is allowed only because the asset will be consuned within the tax year, while depreciation connotes a consistent gradual allocation of the cost of an asset over its useful life. ${ }^{90}$ For this reason, the depreciation argument advances the imquiry no further.

Conversion of assets to personal use is the only clear judicial and statutory precedent relating to the disallowance of expense deductions in the year taken. The Code specifically demes deductions for personal

84. Connery v. United States, 460 F.2d 1130 (3d Cir. 1972); Commissioner v. Anders, 414 F.2d 1283 (10th Cir.), cert. denied, 396 U.S. 958 (1969); Estate of Munter v. Commissioner, 63 T.C. 663 (1975).

85. 430 F.2d 195 (9th Cir. 1970).

86. Id. a! 197.

87. Id. at 198 .

88. Section 167 depreciation in the year of disposition is computcd on the basis of the number of months from the beginning of the tax year through the sale divided by the number of months in the tax year. Treas. Reg. § 1.167(a)-10(b) (1956); see also Fribourg Navigation Co. v. Commissioner, 383 U.S. 272 (1966) (depreciation cost deductible in year asset sold); Schrader v. Commissioner, 34 T.C.M. (CCH) 1572 (1975), aff'd, 582 F.2d 1374 (6th Cir. 1978).

89. See I.R.C. \& 168(d)(2) (1982), amended by Deficit Rcduction Act of 1984, Pub L. No. 98369, § 111(e)(3), 1984 U.S. CODE CONG. \& AD. NEwS (98 Stat.) 494, 633; S. REP. No. 144, 97th Cong., 1st. Scss. 50, reprinted in 1981 U.S. CoDE CoNG. \& AD. NEws 105, 155 ("No recovery deduction will be allowable in the year of an asset's disposition.").

90. Cf. Coca-Cola Bottling Co. v. United States, 487 F.2d 528, 534 (Ct. Cl. 1973) ("The present consumption of an item is the exact opposite of the gradual sale of an asset and it is therefore apparent that current expensing is the antithesis of depreciation."). 
expenses, and the cases interpreting this rule in the business context are legion..$^{91}$ However, the majority's reliance on this principle is indeed, as Justice Stevens wrote, an "ipse dixit." out analysis or support, that distribution of assets in a liquidation is analogous to personal consumption. While it is but a small step to conclude that the deduction inust be disallowed, this logic avoids the real issue whether the distribution to shareholders is a conversion.

The Court never applies its own theory to the deduction disallowance question or to the concrete factual situation in Bliss Dairy. The uncertainty of the application of deduction disallowances in these cases demonstrates the breadth of this gap in the Court's analysis and inilitates against the exclusive definition interpretation of the Court's language. Nonetheless, defining an inconsistent event exclusively as one that would have inandated disallowance of the deduction had it occurred in the same year has one nnajor advantage: it provides a clear starting point to determine whether the tax benefit rule apphes. In this respect, it is the lesser of two evils when coinpared with the only other plausible interpretation of the Court's language: a definition that includes events determined to satisfy a nore theoretical notion of inconsistency.

\section{A Broader Notion of Inconsistent Events}

The Hillsboro Court held that the tax benefit rule will trigger income recognition "only when a careful examination shows that the later event is indeed fundainentally inconsistent with the premise on which the deduction was imitially based."93 The Court may have meant to include within its definition occurrences that would not have led to a disallowance of the prior deduction. There are two instances in which this broader inconsistency might be found. The event could be inconsistent with the statutory provision on which the particular deduction was based, or it could be inconsistent with the broader policies and objectives of the Code. However, neither approach provides enough guidance to taxpayers to make this broader interpretation of inconsistent events a viable solution to the theoretical probleins of the recovery tax benefit rule.

\section{a. Provision-Specific Premises}

In Hillsboro, the bank paid a personal property tax on its stock-

91. For an exhaustive annotation of the disallowance of alleged business deductions under I.R.C. $\$ 262$ (1982), see 4 FED. TAXeS (P-H) I 16,665, at 16,632 (1984); 3 STAND. FED. TAX ReP. (CCH) I 2206, at 27,010 (1984).

92. Hillsboro, 103 S. Ct. at 1160 (Stevens, J., dissenting).

93. Id. at 1143 . 
holders' shares. Section 164(e) allows a deduction if the corporation (1) pays (2) a tax (3) imposed upon its shareholders (4) on their interests as shareholders (5) without reimbursement to the corporation by the shareholders and (6) without a deduction taken by the shareholders for those taxes. If the corporation fails to comply with any of these requirements, the deduction will be disallowed. Moreover, any event negating an element of the deduction would be mconsistent. Thus, the Code provision itself defines the inconsistency. ${ }^{94}$

However, soine Code provisions are quite broad. For example, Bliss Dairy expensed its gram under section 162, which allows a deduction for "all the ordmary and necessary expenses paid or incurred during the taxable year in carrying on any trade or busmess." Simce these provision-specific premises were inet in Bliss Dairy, the Court may have to turn to the broader premises of the tax system itself to find an inconsistency.

\section{b. Systemic Premises}

In Hillsboro, the government argued for a definition of inconsistency that would trigger the tax benefit rule whenever an event was imconsistent with a premise of the tax system, as opposed to a particular Code section. The government claimed that unless the tax benefit rule was applied to Hillsboro National Bank, the final result would be equivalent to allowing the bank a deduction for the paynent of a dividend to its shareholders. This "deduction" would anount to an event inconsistent with the Code's general rule against deductible dividends. The Court noted that section 164(e) contemplates a deductible dividend, ${ }^{95}$ and stated that "[s]ince $\S 164(\mathrm{e})$ represents a break with the usual rules governing corporate distributions, the structure of the Code does not provide any guidance on the reach of the provision."96 In so stating, however, the Court ignores the long accepted notion that deductions should be construed narrowly. ${ }^{97}$

94. But, a distinction must be made between exogenous inconsistent events-events which occur outside the tax world-and eudogenous imconsistent events-events that can be counteracted or removed within the tax system. Only if the mconsistent event cannot be corrected within the tax system should the tax benefit rule provide an endogeuous response to an exogenous event. Thus, not all events that fail to meet the conditions of $\$ 164(\mathrm{e})$ set out in the text should trigger the tax benefit rule. For example, if the shareholder took a deduction for the tax paid by the bank, this would be an inconsistent event, violating premise (6). But the inconsistent event itself could be corrected by denying the shareholder's deduction.

95. Hillsboro, 103 S. Ct. at 1148.

96. Id. at 1149 .

97. "Whether and to what extent deductions shall be allowed depends upon legislative gracc; and only as there is clear provision therefor can any particular deduction be allowed." New Colonial Ice Co. v. Helvering, 292 U.S. 435, 440 (1934); see also Interstate Transit Lines v. Comınissioner, 319 U.S. 590, 593 (1943) ("[A]n income tax deduction is a matter of legislative grace and ... the burden of clearly showing the right to the claimed deduction is on the taxpayer."). But 
Believing the Code offers no guide, lowever, the Court construed section 164(e) broadly, to emphasize the payment aspect of the deduction. Thus, when the funds were later distributed to the sliareliolders, there was no inconsistent event. But if section 164(e) were narrowly construed, so that the payinent of a tax were its integral coinponent, ${ }^{98}$ the result of the Hillsboro case would have been quite different. Since the payment of a tax justified the deduction, the repeal of the tax and refund to the shareholders would be inconsistent with a narrow construction of the section, and the tax benefit rule would apply. ${ }^{99}$

The Bliss Dairy facts reveal a potential inconsistency with another systemic premise of the tax system. Under most circumstances, a business expense can only be deducted once. For example, if a corporation purchases grain for use in its operations, it may deduct the cost of such gram. If the corporation then sells the grain, the money it receives in return will be income and will offset the original deduction. ${ }^{100}$ The purchaser may in turn deduct the purchase price of the gram if it uses the grain in its business. But if the corporation nnakes a gift of the zerobasis grain, the donee may not deduct any of that cost because the donor does not recover any of the original deduction. ${ }^{101}$ Thus, in general, the same cost inay be deducted twice only when the original party has recovered its deduction, and then only to the extent of that recovery.

This general notion, implicit in the Code, is circumvented by the kind of distribution and liquidation scheme engaged in by Bliss Dairy. Under section 336, a corporation recognizes neitler gain nor loss when it distributes property pursuant to a liquidation. Under section 333, shareholders may elect to defer recognition of gain. If they so elect, their basis in the stock of the corporation is allocated to the assets they receive in the liquidation. ${ }^{102}$ The regulations provide that this substitute basis is allocated among the assets according to their fair market values. ${ }^{103}$ Therefore, it is possible for an asset to leave the corporation with a zero basis and have a greater than zero basis in the shareholders' hands.

see Griswold, An Argument Against the Doctrine that Deductions Should Be Narrowly Construed as a Matter of Legislative Grace, 56 HARV. L. REv. 1142, 1144 (1943).

98. Justice Blackmun had urged this interpretation. Hillsboro, $103 \mathrm{~S}$. Ct. at 1164 (Blackmun, J., dissenting). Three Justices concurred with Justice Blackmun in reaching this conclusion.

99. See, e.g., Blum, supra note 3, at 364-65.

100. The grain will have a zero basis due to the prior deduction. Thus all of the sales price will be gain. I.R.C. $\$ 1001$ (a) (1982).

101. In the case of a gift, the donee's basis in the gift is generally the donor's basis; therefore the donee's carryover basis will be zero in this situation. See id. $\$ 1015$ (a).

102. Id. $\$ 334(\mathrm{c})$.

103. Treas. Reg. $\$ 1.334-2$ (1955) provides that the basis in the stock "should be allocated to the various assets received on the basis of their net fair market values (the net fair market value of an asset is its fair inarket value less any specific mortgage or pledge to which it is subject)." 
This step-up in basis is precisely what happened in Bliss Dairy. The corporation distributed grain that had a zero basis because of the corporation's prior deduction. Because of the liquidation, the grain obtained a positive basis in the shareholders' hands. This situation afforded the shareholders a rare opportunity. Since the grain was an expensible asset, they could deduct their stepped-up basis as an ordinary and necessary business expense under section 162 . As a result, the saine grain provided an expense deduction for both the corporation and the shareholders without either having a recovery. It offset incoine at both the corporate and shareholder levels, yet was still available for consumption. While some commentators have found this possibility for a double deduction inconsistent with the general premise that the cost of an asset can be deducted only once, ${ }^{104}$ others have forcefully argued that the provisions of section 336 and section 334 clearly allow this step-up in basis. ${ }^{105}$ Thus, it is unclear whether a distribution of expensed assets in liquidation is inconsistent or not.

The above analysis amply demonstrates the pitfalls the premise inconsistency approach can create. Whether the inconsistency is with a specific Code section or with a premise of the tdx systein itself, the complexities of this approach make it questionable in light of the tax system's need for clarity and simplicity. Whether exclusive or nonexclusive, the inconsistent events approach to the tax benefit rule solves few probleins and creates inany.

\section{E. Nonrecognition Provisions and the Hillsboro Rule}

Even if one is able to determine that an event is inconsistent with a prior deduction, it is still uncertain whether the event will trigger the tax benefit rule. Application of the rule nay conflict with a specific statutory nonrecognition provision. Thus, the second step of the inquiry under the Hillsboro approach is "whether specific nonrecognition provisions prevail over the principle of the tax benefit rule."106 This balancing may prove to be an even more difficult theoretical and practical obstacle to the success of the inconsistent events approach than the

104. See, e.g., Feld, supra note 3, at 462.

105. See Schnee \& White, supra note 3, at 454 . Indeed, a $\S 336 / \S 334$ liquidation seems to contemplate overtly a step-up in basis if the basis of the asset received is below its pro rata fair market value share. Similarly, a step-down in basis is possible if an asset has a high basis in corporate hands, and a low fair market value. Since the allocation of any basis to an expensible asset necessarily decreases the basis left to allocate to other assets, a deduction of the basis of the expensible asset may not be inconsistent. Each dollar that is allocated to the expensible asset is a dollar not allocated to the basis of another asset that may be depreciable or may soon be sold. The lower basis on these other assets reduces potential depreciation and increases potential gain on sale. Thus, the second deduction on the grain is offset by the effects of the basis allocation on other assets, and it is therefore fully consonant with the policies and aims of the Code.

106. Hillsboro, $103 \mathrm{~S}$. Ct. at 1147. 
determination whether an event is inconsistent. Although the Court supplies the test, it gives no guidance as to the test's application, either by discussing the policies to be considered, or by listing the factors to be given weight.

In Bliss Dairy, for example, the tax benefit rule conflicts directly with the nonrecognition provisions of section 336 . The Court thus proceeded to determine whether the gain produced by application of the tax benefit rule to the corporation "is the sort of gain that goes unrecognized under $\S 336 . " 107$ The Court interpreted the legislative history of section 336, analogized to section 337, and concluded that Congress meant section 336 to shield only niarket appreciation, not ordinary income. ${ }^{108}$ Therefore, the tax benefit rule, which affects income but not market appreciation, overrides section 336, and Bliss Dairy had to recognize income.

While the Court's interpretation of the legislative history is plausible, it neither takes into account nor refutes several forceful arguments reaching a different conclusion. ${ }^{109}$ It is far froun clear, for a variety of reasons, that section 337 should be used to interpret section 336. First, section 337 was passed to aid corporations; ${ }^{110}$ it thus seen1s inappropriate to use it as a weapon against thein in the interpretation of section 336. Second, section 337 was designed to emulate section 336; therefore, section 336 should control section 337 and not vice versa. Third, although the argument for parity between these sections was once appealing, the sections are no longer congruous. ${ }^{11}$ Last, the tax benefit rule's apphication to liquidations covered by section 336 has been litigated for over twenty years with no consistent result. ${ }^{12}$ It is thus of doubtful relevance that Congress apparently acquiesced to the rule's application in section 337 liquidations.

Fron the above analysis, it is apparent that the determination of whether the tax benefit rule should prevail over a nonrecognition provision is complex, confusing, and uncertain. To complicate this step of the imconsistent events approach further, the Court explicitly recognizes only conflicts between the tax benefit rule and nonrecognition provisions in the Code. Many nonrecognition principles, lowever, have de-

107. Id. at 1150.

108. See supra notes $73-78$ and accompanying text.

109. See Blum, supra note 3, at 367; see also Tennessee Carolina Transp., lnc. v. Commissioner, 65 T.C. 440,453 (Tannenwald, J., dissenting), aff d, 582 F.2d 378 (6th Cir. 1978), cert. denied, 440 U.S. 909 (1979).

110. See Blum, supra note 3, at 367; Morrison, supra note 38, at 919.

111. For example, $\S 336$ requires imcone recognition on LIFO imventory, I.R.C. $\S 336(b)$ (1982), while $\S 337$ requires income recognition on all inventory, id. $\S 337(b)(1)$, unless substantially all of it is sold in one transaction to one person. $I d . \S 337(\mathrm{~b})(2)$.

112. See supra notes 20-38 and accompanying text. 
veloped outside the statutory framework. For example, courts have long held that a donor realizes no income upon the making of a gift. ${ }^{113}$ The difficult task of determining whether the tax benefit rule should be overcome by a nonrecognition doctrine becomes only more arduous when a judicial doctrine is substituted for a congressional mandate. Under both judicial and statutory authority, the mconsistent events approach provides hittle guidance to the taxpayer. Thus, the second step of the Court's analysis-determining whether a nonrecognition provision prevails -is as confusmg as the first step-determining whether an inconsistent event has occurred at all.

\section{III}

\section{An Asset-Based Tax Benefit Rule}

The Court's inconsistent events approach is a circuitous solution to a straightforward problem. The classic definition of the tax benefit rule, under which income is not recognized until there is a recovery, operates correctly in most situations. The Court discards the recovery rule, however, because it fails under some narrowly defined circumstances. A more appropriate strategy is to devise a separate but compatible rule apphicable only to those situations in which the classic tax benefit rule does not provide an adequate solution.

It is clear that the tax benefit rule must be modified, as the recovery requirement provides an enormous loophole for taxpayers engaging in "nonrecovery" transactions. The major flaw in the classic approach is exposed by South Lake Farms, Tennessee Carolina, and Bliss Dairy. In each of these cases, ${ }^{114}$ the taxpayers disposed of assets upon which deductions that would affect potential gain had been taken. Gain was affected either because the deductions had reduced the bases of the assets, or because the deductions had enhanced the assets' fair inarket values. When the taxpayers attempted to escape taxation on this "gain," the tax benefit rule should have been triggered. The inconsistent events approach, however, cuts out the core of the recovery tax benefit rule in an attempt to capture these tax benefit situations with an all-encompassing solution. The result is vaguely defined and leads to unpredictable taxation.

This Comment proposes an asset-based tax benefit rule that provides a practical and simple method to cover cases such as those faced by the Hillsboro Court. This rule concentrates on two types of assets: those with bases reduced by deductions, and those with fair market values enhanced by deductions. The proposed rule treats all disposi-

113. Campbell v. Prothro, 209 F.2d 331, 336 (5th Cir. 1954); see infra text accompanying notes 120-28.

114. See supra notes $20-38$ and accompanying text. 
tions ${ }^{115}$ (and conversions) of such assets as constructive sales. In doing so, the asset-based approach produces realized gain. However, recognition is limited to the lesser of the original deduction producing the $\operatorname{tax}$ benefit and the realized gain on the subsequent disposition. Any nonrecognition provision that conflicts with this recognition will prevail over the asset-based tax benefit rule only if it is based on a concept of economic continuity. This basic definition of the asset-based tax benefit rule will be expanded below, and the proposed rule will be contrasted with the Hillsboro inconsistent events approach.

\section{A. Dispositions of Assets}

In the most general application of the proposed approach, any disposition of an asset upon which deductions have been taken should trigger the tax benefit rule. ${ }^{116}$ The disposition of the asset, treated as a constructive sale, would produce a realization of gain. Under the assetbased tax benefit rule, gam is recognized only up to the extent of the origimal deductions affecting basis.

\section{Sales}

It is unclear whether the Hillsboro inconsistent events approach would be applied in the case of a sale. If the asset upon which deductions have been taken were sold in the prior year, would those deductions have been disallowed? Does the later sale produce some inconsistency witl a premise of the tax system? This is a noot question in the sale context, because application vel non of the inconsistent events approacli will always produce the same net result for the tax-

115. In this context, a disposition is any event that alters the ownership of an asset by a particular taxpaying entity, including partial changes in ownership. If a taxpayer disposes of a portion of indistinguishable assets, the asset-based tax benefit rule should recapture the lowest possible anount. For example, if a taxpayer disposes of a portion of his grain supply, it will be inpossible to tell which deduction was associated with the purchase if the grain has been purchased at different tines and different prices. The benefit of the doubt should be resolved in favor of the taxpayer, and the graim should be presuined to have been purchased at the lowest price.

116. Of course, the tax benefit rule cannot override specific congressional intent mandating a contrary result. For example, though depreciation recapture is essentially a tax benefit concept, it is exclusively governed by I.R.C. $\$ \S 1245$ and 1250 , which provide many exeinptions not allowed by the asset-based tax benefit rule proposed in this Comment. I.R.C. $\S 1245$ (1982), amended by Deficit Reduction Act of 1984, Pub. L. No. 98-369, § 111(e)(5), (10), 1984 U.S. CODE CoNG. \& AD. News (98 Stat.) 494, 633-34; id. $\$ 1250$, amended by Deficit Reduction Act of 1984, Pub. L. No. 98-369, § 712(a)(1)(B), 1984 U.S. CodE CoNG. \& AD. NEws (98 Stat.) 494, 946.

A contrary congressional intent also arguably exists in the rules treating transfers upon death. See id. $\S \S 102$, 1014. Normally, the recipient of property gains a fair inarket value basis, yet the decedent recognizes no income. However, the congressional intent not to tax the decedent, while long accepted, is not as explicit as the depreciation recapture provisions noted supra that directly address tax benefit situations. Thus, a disposition for the purposes of the asset-based tax benefit rule includes transfers by reason of death. On nonrecognition, see infra Section $D$. 
payer. If the rule is triggered, the taxpayer recovers the original deduction. If the asset is sold, the taxpayer will also recover the original deduction, as the asset's basis will be zero due to prior expensing. ${ }^{17}$

The application of the inodel rule to sale situations is quite simple. The sale produces realized gain in the ainount of the excess of the value received over the asset's basis. If the realized gain is greater than the amount of the original deductions, the asset-based tax benefit rule requires recognition of gain up to the extent of the deductions, ${ }^{118}$ as there is no longer a tax benefit inequity in the systein once these deductions have been recovered. General incoine tax principles inay require further recognition of gain realized on the sale. If, however, the realized gain is less than the original deductions, the recognized gain is limited to the realized gain, for a taxpayer cannot recognize inore gain than is realized. ${ }^{119}$

\section{Gifts}

A more difficult tax benefit question is posed when expensed assets are given as personal gifts. If such a gift were made in the year the orignial deductions were taken, the deductions would be disallowed under the inconsistent events approach on the authority of section

117. While the grain may be a capital asset in certain situations, the nature of the gain or loss on disposition should be ordinary, simce it is an asset used as a supply in the ordimary course of business. See Corn Prods. Ref. Co. v. Commissioner, 350 U.S. 46 (1955). Thus, if an asset has appreciated or depreciated in value, a sale will produce ordmary income in the amount of gain realized. If the tax beuefit rule is appied, the original deduction is recovered, and presunably produces ordinary income. If the asset has appreciated in value, any gaim over and above the recovered deduction will be ordinary income. If the asset has depreciated in value, the recovery of the deduction under the tax benefit rnle will presumably increase the asset's basis; the sale will thus produce an ordinary loss that will offset, to some extent, the ordimary gam produced by the tax benefit rule. The net result will be recognized gam in the amount of realized gain-the same result that would occur without application of the tax benefit rule.

For example, if a farmer purchases and expenses grain worth $\$ 25,000$, his basis in the grain will be zero. If he later sells all of the grain for $\$ 15,000$, his uet income will be $\$ 15,000$ with or without application of the imconsisteut events approacl. If the rule is not applied, general incoune tax principles produce a realized and recognized gaim of $\$ 15,000$ (value rcceived less adjusted basis). If the Hillsboro rule is applied, the $\$ 25,000$ deduction is recovered, and the farmer has $\$ 25,000$ in ordinary income. This income recognition slould increase the basis of the grain sold to $\$ 25,000$, its tax-paid cost. Thus, the tax result of a sale triggering the inconsistent events approach is a $\$ 10,000$ loss ( $\$ 15,000$ value received on the sale less $\$ 25,000$ adjusted basis). Netting out this $\$ 10,000$ loss and the $\$ 25,000$ income produced by the tax benefit rule (both ordinary imcone, see Corn Products, supra) produces $\$ 15,000$ in ordinary income, the same result. If the grain has appreciated in value, the same result occurs.

118. Recapture is limited to the portion of those deductions attributable to the asset sold. For example, if a farmer sells two-thirds of the grain he originally purcliased for $\$ 25,000$, the assetbased tax benefit rule will require recogintion not in excess of $\$ 16,666$. If the realized gain is greater than this amount, general tax principles may require further recognition. See supra note 115.

119. This assumes that realization is limited to the excess of the amount received over basis. See I.R.C. § 1001(a) (1982); infra Section $E$. 
262. ${ }^{120}$ The next step of the inquiry requires a search for a conflicting nonrecognition provision. Although there is no statutory provision shielding the donor in this context, ${ }^{121}$ courts have consistently characterized the inaking of a gift as a nonrecognition event. ${ }^{122}$

For example, in Campbell v. Prothro, ${ }^{123}$ the taxpayer deducted the cost of raising certain cattle and then gave the cattle away. When the donee subsequently sold the cattle, the Commissioner attempted to impute the proceeds of the sale to the taxpayer. The Fifth Circuit rejected this approach, noting that if the proceeds were taxable to the donor, "then every appreciation in value of property passing by gift is realized income. We know that this is not so, and that . . . congress [sic] has never enacted legislation so providing." ${ }^{24}$ This was not the first time the Service had atteinpted to use the assignment of incoine theory to impute income to the donor of a gift. However, most courts have rejected such an application of the theory. ${ }^{125}$

These cases, however, did not address the tax benefit rule. Although the Commissioner has since argued that the tax benefit rule should apply when a gift of expensed inventory is inade, ${ }^{126}$ he has not

120. Gifts are possible in a business context, but their deductibility is severely limited by I.R.C. $\$ 274$ (b) (1982). See also Rev. Rul. 55-531, 1955-2 C.B. 520.

121. Sections 1245 and 1250 reach dispositions of depreciable property by gift, but do not require incoine recognition to the donor. Rather, the property retains its potential for recapture in the hands of the donee. See I.R.C. $\$ \$ 1245(b)(1), 1250$ (d)(1) (1982); see also S. REP. No. 1881, 87th Cong., 2d Sess. 97-98, reprinted in 1962 U.S. CODE CONG. \& AD. NEws 3304, 3400-01.

122. This doctrine does not include "net gifts" and "part sales, part gifts." Diedrich v. Conmissioner, 102 S. Ct. 2414 (1982) (donor realizes incoine on gift to extent gift tax paid by donee exceeds basis); Johnson v. Commissioner, 495 F.2d 1079 (6th Cir. 1974) (donor realizes incone on gift to extent that money received exceeds basis), cert. denied, 419 U.S. 1040 (1974); 212 Corp. v. Commissioner, 70 T.C. 788 (1978) (part sale, part gift); see infra notes 187-90 and accompanying text.

123. 209 F.2d 331 (5th Cir. 1954); see also 67 HARv. L. Rev. 1425 (1954) (noting this case).

124. Campbell, 209 F.2d at 336.

125. See White v. Brodrick, 104 F. Supp. 213 (D. Kan.), appeal dismissed, 198 F.2d 751 (10th Cir. 1952) (taxpayer realizes no income by donating harvested crop to charity); Rogers v. Commissioner, 38 T.C. 785 (1962) (no assignment of income in gift of timber lease to church); SoRelle v. Commissioner, 22 T.C. 459 (1954) (no assignment of income in gift of land and unharvested, matured crops); Estate of Farrier v. Commissioner, 15 T.C. 277 (1950) (no assignment of income in gift of appreciated value cattle); Smith v. Commissioner, 1967 T.C.M. (P-H) I 67,229, at 1274. It is significant that the Internal Revenue Service has chosen not to appeal inost of these cases. But cf. I.T. 3932, 1948-2 C.B. 7 (father assigned income of fair market value of cattle where son sold cattle eight months after receiving them as a gif) (revoked by Rev. Rul. 55-531, 1955-2 C.B. 520); I.T. 3910, 1948-1 C.B. 15 (fair market value of farin product donated to charity includable in income; charitable deduction allowed; expenses of production allowed); see also Parmer v. Commissioner, 468 F.2d 705 (10th Cir. 1972) (lessor's donation to charity of crop shares due as rental held to be assignment of income); Weinberg v. Comnnissioner, 44 T.C. 233 (1965) (assignment of crops to newly forned corporations ruled assignment of income of proceeds of earlier sale, crops already larvested and sold at timie of assignment).

126. See Rev. Rul. 63-66, 1963-1 C.B. 13, modified by Rev. Rul. 75-11, 1975-1 C.B. 27 (transfer of receipts evidencing crop shares receivable as rent does not avoid income recognition); Rev. Rul. 55-531, 1955-2 C.B. 520 (revoking I.T. 3932, 1948-2 C.B. 7) (gift of property lield for sale in 
yet made this argument before the courts. Furthermore, the Commissioner has not ruled that the tax benefit rule is applicable to gifts of assets other than inventory. ${ }^{127}$ Under the inconsistent events approach of the Hillsboro Court, the conflict between the tax benefit rule and this judicial nonrecognition provision must be examined; yet the Court's approach provides no guidance as to which doctrine should prevail.

Under the asset-based tax benefit rule, a gift of an expensed asset is treated as a constructive sale. The taxpayer realizes as gain the excess of the gift's fair market value at the time it is given over its basis. If this realized gain is greater than the origmal deductions, recognized gain is limited to the origmal deductions. If the realized gam is less than the original deductions, recogmition is limited to realized gain.

For exainple, if a farmer purchases grain for $\$ 25,000$ and deducts the cost, his basis in the grain will be zero. His subsequent gift of the grain to his daughter when its fair market value is $\$ 10,000$ will be treated as a constructive sale. Simce the farmer's basis is zero and the anount he receives (constructively) is $\$ 10,000$, his reahzed gain is $\$ 10,000$. Even though his original deduction was $\$ 25,000$, he will recognize only $\$ 10,000$-his realized gain.

If the gift is given in a business context, it will produce a deduction, subject to statutory limitations. ${ }^{128}$ If the gift is given in a personal context, no deduction is allowed. The proposed rule thus produces harsh, but correct, results: the taxpayer bears the cost of her personal gift to the extent she has received a tax benefit from it in prior years. This is the result an ideal rule should generate.

\section{B. Conversions}

The results under the inconsistent events approach are even inore difficult to predict when conversions of assets are involved. For exainple, if a sole proprietor converts an expensed asset to personal use, it is

ordmary course of business not includable in donor's income; inventory adjustment required and no items of cost with respect to donated property deductible in current or subsequent year); Rev. Rul. 55-138, 1955-1 C.B. 223 (no income on donation of inventory to charity, but inventory adjustinent required to prevent double deduction).

127. A current year inventory-account adjustment allows the Commissioner to disallow costs incurred in prior years without reopening the tax returns from those years, because the opening inventory account represents an accuinulation of prior years' costs of mventory (disregarding the precise inethod of accounting within the inventory account).

128. I.R.C. $\$ 274(b)(1)$ (1982) generally linits deductions for gifts to any individual to $\$ 25$ per year. For the purposes of $\S 274$, a gift is generally an item excludable from the recipient's gross incoine via I.R.C. $\$ 102$ (1982). Soine business "gifts" may therefore not be subject to these limitations if the recipient pays income tax on the value of the property.

Thus, the inodel rule closes a loophole allowing businesses to avoid the statutory gift limitations by giving away assets previously expensed. The maximum deduction is limited by I.R.C. $\S 274$; the rest is absorbed by the taxpayer. 
unclear whether the inconsistent events approach will require income recogmition. Recapture provisions do not apply to such a case because there is no disposition. If the conversion had occurred in the year of expensing, however, the deduction might have been disallowed under the authority of section 262 , which prohibits deductions for personal expenses. Thus, the Hillsboro tax benefit rule may apply. ${ }^{129}$

There are no specific statutory nonrecognition provisions or judicial principles that challenge the tax benefit rule in a conversion. Nevertheless, the rule may not prevail because there is generally no tax unless there is a transaction or event, and when assets are converted to personal use, no transaction occurs. ${ }^{130}$ If the purpose of the tax benefit rule is to approximate transactional accounting, then presumably there should be no tax on a transaction or event that is not itself taxable. However, a nontaxable event may be part of an integrated series that should produce tax consequences when viewed as a whole. ${ }^{131}$ Viewing a conversion in this light, the tax benefit rule should apply.

The asset-based tax benefit rule, however, focuses on dispositions. It is therefore necessary to define a disposition as encompassing a conversion. Such a definition is theoretically sound when the tax system is viewed as divided imto two spheres. The first encompasses, but is not limited to, income-producing activities. Simce the goal of the system is to tax imcome rather than receipts, a taxpayer may generally deduct expenditures within this 'sphere, either immediately or over time. ${ }^{132}$ Expenses incurred in operatimg a trade or business, ${ }^{133}$ owning business assets, ${ }^{134}$ and producing imcome ${ }^{135}$ are all deductible. ${ }^{136}$ The second

129. Prior to the Deficit Reduction Act of 1984, Pub. L. No. 98-369, 1984 U.S. CODE CONG. \& AD. News (98 Stat.) 494, $\S 311$ of the Code presented a variation of the conversion problem. Under I.R.C. $\$ 311$ (1982), a corporation could distribute an expensed asset to a shareholder and rely on the nonrecognition mandate of $\S 311$. However, Congress has solved this problem by treating all distributions of property with fair market value in excess of basis as constructive sales, in line with the approach of the asset-based tax benefit rule. See I.R.C. §311(d) (1982), amended by Deficit Reduction Act of 1984, Pub. L. No. 98-369, § 54(a)(1), 1984 U.S. Code Cong. \& AD. NEws (98 Stat.) 494, 568-69; see also infra notes 201-02 and accompanyimg text.

130. See, e.g., B. Bittker \& J. Eustice, Federal Income TaXation of Corporations AND SHAREHOLDERS I] 14.01 (1979).

131. See generally R. Paul, P. Zimet \& M. Paul, Step Transactions, im Selecred Studies IN FEDERAL TAXATION 200 (2d ser. 1938).

132. Some expenditures are deductible even though they do not contribute to imcome production, because they further important pohicy goals. E.g., I.R.C. $\S 170$ (1982) (charitable deductions), amended by scattered sections of Deficit Reduction Act of 1984, Pub. L. No. 98-369, 1984 U.S. CODE Cong. \& AD. News (98 Stat.) 494.

133. Id. $\S 162$ (busimess expenses), amended by Deficit Reduction Act of 1984, Pub. L. No. 98369, §§ 512(b), 2354(d), 1984 U.S. CODE CoNG. \& AD. News (98 Stat.) 494, 863, 1102.

134. Id. § 167 (depreciation), amended by Deficit Reduction Act of 1984, Pub. L. No. 98-369, $\S$ 1064, 1984 U.S. CODE CoNG. \& AD. NEWs (98 Stat.) 494, 1047; id. \& 168 (accelerated cost recovery), amended by scattered sections of Deficit Reduction Act of 1984, Pub. L. No. 98-369, 1984 U.S. CODE CONG. \& AD. NEws (98 Stat.) 494; see also id. § 179 (expensing), amended by Deficit 
sphere is characterized by expenditures that are not generally deductible. This sphere encompasses "personal, hiving, or family expenses,"137 and other nondeductible expenditures. ${ }^{138}$

Under the asset-based approach, any transfer of an asset from the deductible sphere to the nondeductible sphere will trigger the tax benefit rule because it will be a disposition (at least theoretically) from one sphere to the other. For example, if a sole proprietor converts an expensed asset from busmess to personal use, the asset-based approach will treat the conversion as a disposition from the deductible sphere to the nondeductible sphere. This movement between spheres will be a realization event that will trigger the tax benefit rule. ${ }^{139}$

\section{Deductions That Do Not Directly Affect Basis}

By focusing on deductions that affect basis, the definition of the asset-based tax benefit rule set forth above excludes a major tax benefit problem. In many tax benefit cases, deductions affect the fair market value of an asset rather than its basis. In Campbell v. Prothro, ${ }^{140}$ for example, the asset (cattle) was not expensed, but appreciated in value due to the use of other assets (such as feed) that were expensed. There are thus two distinct categories of cases: those involving the disposition of expensed assets, and those involving the disposition of assets with values enhanced by expenses. The inconsistent events approach is confusing enough when apphed to the former; it is less comprehensible when applied to the latter.

For example, in Commissioner v. South Lake Farms, Inc. ${ }^{141}$ the taxpayer, a corporation, deducted the cost of growing crops. Before harvest, the shareholders sold the corporation. The buyer allocated part of the purchase price of the corporation to the basis in the crop upon the immediate liquidation of the corporation under section 336 . When the crop was harvested and sold, the buyer thus had less gain.

Reduction of 1984, Pub. L. No. 98-369, § 13, 1984 U.S. Code Cong. \& AD. News (98 Stat.) 494, 505 .

135. Id. $\S 212$ (expenses of incoine production).

136. Doyle v. Mitchell Bros. Co., 247 U.S. 179 (1918).

137. I.R.C. $\S 262$ (1982) (personal expenses).

138. See, e.g., id. $\S 265$ (expenses incurred in production of tax-free income nondeductible), amended by Deficit Reduction Act of 1984, Pub. L. No. 98-369, §§ 16(a), 56(c), 1984 U.S. CODE Cong. \& AD. NEws (98 Stat.) 494, 505, 574.

139. In a partial conversion, the proposed rule operates sinilarly. For example, if a sole proprietor uses an automobile $50 \%$ of the time in her business, she is entitled to $50 \%$ of the normally allowable depreciation deduction. See Rev. Proc. 82-61, 1982-2 C.B. 849. If the taxpayer increases personal use to $75 \%$, she has constructively disposed of $25 \%$ of the automobile from the deductible sphere to the nondeductible sphere. Thus, one-half of the depreciation deductions must be recovered.

140. 209 F.2d 331 (5th Cir. 1954); see supra text accompanying notes 123-25.

141. 324 F.2d 837 (9th Cir. 1963); see supra text accompanying notes 20-29. 
The Ninth Circuit held the tax benefit rule inapplicable to the purchased corporation because it had no recovery. ${ }^{142}$

The inconsistent events approach might have required a different result. Whether the taxpayer would still have gotten a deduction if the corporation had been sold and liquidated in the saine year it took that deduction is not at all clear and raises the saine questions raised by Bliss Dairy. ${ }^{143}$ Additionally, since the expenses deducted were actually used in the business of the corporation, the sale and liquidation of the corporation inay not have violated the premise behind these deductions. But the point reinains that no one paid tax on the income associated with the expenses deducted. ${ }^{144}$ This may violate the tax systen's general policy that the entity that deducts expenses associated with producing mcoine should pay tax on that incoine when it is realized.

However, if the tax benefit rule does apply to South Lake Farms, it logically reaches all expenses made that enhance the value of assets on hand at liquidation. Such expenses include a portion of all overhead attributable to the assets, as well as a portion of all expenses that enhance the value of the liquidating corporation as a going concern. As Justice Stevens put it, "all corporate paper towels, paper clips, and pencils that remain on hand will become income as a result of the liquidation." ${ }^{145}$ This result is unnecessary to effect consistent taxation of similarly situated taxpayers.

To cause taxpayers to recapture the tax benefit of prior deductions such as those in South Lake Farms, the asset-based tax benefit rule treats the distribution upon liquidation as a constructive sale. Any gain will be realized, and the taxpayer will recognize imcoine up to its prior deductions. For exainple, assume that a farming corporation deducts

142. South Lake Farms, 324 F.2d at 839.

143. See supra Part II.

144. The shareholders of South Lake Farms sold their shares to the purchasing corporation. Presumably, the purchaser was willing to buy the corporation for the value of the assets less any tax liability South Lake Farms owed. If the purchaser had bought the assets directly, rather than the whole corporation, it would have allocated its cost basis to the crops. Then, when the crops were sold, only the difference between that basis and the selling price would be taxable as gain. The purchasing corporation would have paid no tax on the income associated with South Lake Farms' expenses because those expenses enhanced fair market value, which was the purchaser's cost and hence basis. If the purchasers had bought the crops directly froin South Lake Farms, South Lake Farms would have had gross incoine to the extent of the purehase price, and paid tax accordingly. The shareholders' shares would then have been worth the fair inarket value of the crop less the tax hability to the corporation, and the purchasing corporation would have been willing to pay no more than this amount for the shares. By selling their shares to the purchaser who in turn hiquidated South Lake Farms, the shareholders received full fair market value, the purchaser paid full fair market value, and South Lake Farms had no recognition and therefore no income. Thus the liquidating corporation avoided tax to the extent that the price was not paid to the corporation, but to its shareholders.

145. Hillsboro Nat'l Bank v. Commissioner, 103 S. Ct. 1134, 1162 (1983) (Stevens, J., concurring and dissenting). 
$\$ 25,000$ spent to plant a crop worth $\$ 35,000$ on liquidation. Since the costs of planting the crop have been deducted, its basis is zero. The realized gain froin the constructive sale is $\$ 35,000$ (fair inarket value less basis). However, recognition is limited to the $\$ 25,000$ previously deducted. The ren1aining $\$ 10,000$ in realized gain goes unrecognized, as it is beyond the scope of the tax benefit rule.

This general approach inust be limited, however, by a boundary designating which value-enhancing deductions should be subject to tax benefit rule treatinent. Without such a rule, all expenses of a going concern would potentially be subject to recapture. To allow the rule to go this far would be to subject it to the saine criticisins encountered by the Court's approach. ${ }^{146}$ Thus a cutoff is required-only an expense substantially all of which affects the potential gain of an asset in question is subject to the tax benefit rule. This excludes utility expenses, overhead, office expenses, and advertising-expenses that contribute to other areas of the taxpayer's business, and only minimally affect the basis of the asset that is disposed. ${ }^{147}$

\section{Nonrecognition Provisions}

Once it is determined that the tax benefit rule should apply to an event, the rule nust be weighed against any nonrecognition provisions. As indicated above, the Court's approach to this question will prove difficult. ${ }^{148}$ A statutory provision cannot prevail over the tax benefit rule without so stating unless an extremely forceful congressional policy niandates such a result. This policy would have to be strong enough to overcoine the policy that the Court seems to apply-judicial principles proinoting the general goals of the tax systein are considered to be exceptions to particular Code provisions. This approach has supported the tax benefit rule override of section 337, and now of section 336.

One Code section that could potentially outweigh the tax benefit

140̄. See id. (Stevens, J., concurring and dissenting).

147. Arguably, every expense ever inade by a business increases the value of the business. Thus, when an entire business is hquidated, these expenses should be subject to the asset-based tax benefit rule. However, since a business' historical expenses will greatly exceed its current value, these expenses cannot qualify for recapture under the asset-based tax benefit rule. A rational taxpayer will not make an expenditure that will increase the value of an asset by only a portion of the expenditure unless the expenditure serves another purpose. Thus, such expenses fail the test set out in the text.

The "substantial" standard is subject to criticism because it may lcad to adininistrativc difficulties. However, most assets affected by this standard (i.e., crops) will have a relatively short lifc in the taxpayer's hands, thus limiting the historical inquiry. Moreover, the deduction must affect fair market value; thus expenses that maintain fair market value are excluded.

148. See supra text following note 112 . 
rule is section $351 .^{149}$ Scction 351 provides for tax-free treatment in some incorporations and transfers of property to existing corporations. The congressional mandate allowing for changes in business form without taxation is clear. ${ }^{150}$ The Supreme Court faced the question whether this policy overrides the tax benefit rule in Nash v. United States. ${ }^{151}$ In that case, the taxpayer had certain accounts receivable subject to a bad debt reserve. The taxpayer transferred these accounts to a newly formed corporation, and the Commissioner attempted to assess the taxpayer on a tax benefit theory. But the Court avoided the tax benefit rule and decided the case on a narrower footing. The unanimous opinion held that the transaction was not a recovery since the bad debt reserve was reasonable and the taxpayer received securities in the new corporation equal to the value of the accounts less the reserve. ${ }^{152}$ The Hillsboro Court reasoned that Nash did not involve an inconsistent event. ${ }^{153}$

Neither decision discussed whether the outcome would have been different if the bad debt reserve had not been reasonable. Where too nany debts have been deened uncollectible, the fair market value of the receivables is greater than the face value less the bad debt reserve. ${ }^{154}$ A transfer of receivables under such circumstances might be an inconsistent event since some of the additions to the reserve were erroneous. Had it been known in the year the additions were made

149. I.R.C. § 351(a) (1982) provides: "No gain or loss shall be recognized if property is transferred to a corporation by one or more persons solely in exchange for stock or securities in such corporation and immediately after the exchange such person or persons are in control (as defined in section 368(c)) of the corporation."

150. Section 351 has been part of the tax law since the Revenue Act of 1921, § 202(c)(3). The legislative history provides that:

Probably no part of the present imcome tax law has been productive of so much uncertainty or has more seriously interfered with necessary business readjustments. The existing law makes a presumption in favor of taxation. The proposed Act modifies that presumption . . . and specifies .. . certain classes of exchanges on which no gain or loss is recognized . . . . These classes [include situations] . . . where an individual or individuals transfer property to a corporation and after such transfer are in control of such corporation.

The preceding amendments, if adopted, will, by removing a source of grave nncertamty and by eliminating many technical constructions which are economically unsound, . . . permit busimess to go forward with the readjustments required by existing conditions.

S. REP. No. 275, 67th Cong., 1st Sess. at 11-12 (1921), reprinted in 1939-1 C.B. (pt. 2) 181, 188-89. The courts have also accepted this interpretation of $\S 351$ and its predecessor. See Portland Oil Co. v. Commissioner, 109 F.2d 479, 488 (1st Cir.), cert. denied, 310 U.S. 650 (1940).

151. 398 U.S. 1 (1970).

152. Id. at 4.

153. $103 \mathrm{~S}$. Ct. at 1147.

154. See, e.g., Rev. Rul. 78-280, 1978-2 C.B. 139; see also Schnee \& White, supra note 3, at 455-56. 
that some were faulty, the Service would have disallowed them. ${ }^{155}$ Thus, a taxpayer's receipt of stock or securities with a fair market value exceeding the value of the reserve might be an imconsistent event that should trigger the tax benefit rule.

Once the rule has been triggered, a court could construe "gam" as used in section 351 to include only market appreciation, so that the tax benefit rule would prevail over section 351 . This construction of "gam" applies to section 337, and now to 336 . However, the policy of precluding tax on a inere change in form ${ }^{156}$ may be so strong that section 351 would overcoine the tax benefit rule. Section 351 specifically overrides sections 1245 and $1250,{ }^{157}$ but does not override other tax primciples, such as the assignment of income doctrime. ${ }^{158}$ Furthermore, taxpayers may not distort their imcome through a section 351 exchange. Thus, the Commissioner may alter accountmg methods ${ }^{159}$ or reallocate deductions from the individual to the corporation ${ }^{160}$ upon incorporation. Once agam, the imconsistent events approach produces an indeterminate result.

In contrast, the asset-based tax benefit rule offers a clear solution to the problems created by nonrecognition provisions and policies in

155. Only reasonable additions to the reserve are allowable. See Treas. Reg. $\$ 1.166-4$ (a) (1976).

156. See supra note 150 . The legislative history indicates that the predecessor of $\$ 351$ was passed to ensure fairness. During the confidential hearings on the Revenue Act of 1921, Dr. T.S. Adams, Special Treasury Advisor, stated:

If one man incorporates his property or if a group of men incorporate their property, that mere fornahity, $\mathrm{m}$ one sense, of placing the property in corporate ownership subjects them to a tax, provided the stock received has a market value in excess of the cost of the property to the individual.

... I can not beheve that there is enough difference in the ownership of the property and the stock under such circuunstances to justify us in recognizing taxable gain or deductible loss.

Senator Siminons concurred:

Imposing taxes on things of that sort is what the Secretary, as I rcmember, characterized as a clog upon enterprise. There is no justification for a tax of that sort. It is one of the forins of busimess. There really has been no profit made. It is just a change in the kind and character of title to the property; that is all.

Confidential Hearings on H.R. 8245 Before the Senate Comm. on Finance, 67th Congress, 1st Sess. 30 (1921) (statements of T.S. Adams, Treas. adviser, and F. Simmons, Senator); see also S. REP. No. 275, 67th Cong., 1st Sess. 181, reprinted in 1939-1 C.B. (pt. 2) 181, 188-89.

157. See I.R.C. $\S \S 1245(b)(3), 1250$ (d)(3) (1982).

158. Brown v. Commissioner, 115 F.2d 337 (2d Cir. 1940) (claim for legal fees); Weimberg v. Commissioner, 44 T.C. 233 (1965), rev'd on other grounds sub nom. Commissioner v. Sugar Daddy, Inc., 386 F.2d 836 (9th Cir. 1967), cert. denied, 392 U.S. 929 (1968).

159. Palmer v. Commissioner, 267 F.2d 434 (9th Cir. 1959) (change froin completed contract accounting to percentage of completion accounting under I.R.C. $\S 446$ (b) upon incorporation).

160. Rooney v. United States, 305 F.2d 681 (9th Cir. 1962) (taxpayer transfered crop to corporation and attempted to take personal deductions for crop expenses up to date of transfer, expenses reallocated to corporation under $\S 482 ; \S 482$ controls $\S 351$ ). But of. Fanning v. United States, 568 F. Supp. 823 (E.D. Wash. 1983) (no reallocation under $\S 482$ because no distortion of income). 
the Code, based upon a standard of economic continuity. Nonrecognition transactions can be divided into four general categories. ${ }^{161}$ First, the Code affords nonrecognition treatment to certain realization events that might otherwise pose a hardship to the taxpayer. ${ }^{162}$ Second, the Code requires nonrecognition in transactions that have the sole purpose of creating a loss. ${ }^{163}$ Third, nonrecognition encompasses transactions where no income is produced because under current tax theory there is no realization event. ${ }^{164}$ The asset-based tax benefit rule will override the nonrecognition policies in these categories because a disposition has taken place.

The fourth and inost extensive use of nonrecognition occurs "where in theory the taxpayer may have realized gain or loss but where in fact his economic situation is the same after as it was before the transaction."165 This sort of economic continuity nay be further divided into two types of transactions. Under the first, nonrecognition is afforded to:

certain specific exchanges of property in which at the time of the exchange particular differences exist between the property parted with and the property acquired, but such differences are more formal than substantial. As to these, the Code provides that such differences shall not be deemed controlling, and that gain or loss shall not be recognized at the time of the exchange. The underlying assumption of these exceptions is that the new property is substantially a continuation of the old investment still unliquidated. ${ }^{166}$

The economic continuity theory of nonrecognition exeinpts dispositions that would otherwise fall under the tax benefit rule. The Code

161. Cf. M. Chirelstein, Federal Income Taxation \$ 15, at 251 (1982); see also Note, Previously Expensed Assets, supra note 38, at 1647-51.

162. See, e.g., I.R.C. $\$ 121$ (1982) (one-time exclusion of gain); id. $\$ 1034$ (rollover of gain on purchase of new residence), amended by Deficit Reduction of 1984, Pub. L. No. 98-369, \& 1053(a), 1984 U.S. CoDE CoNG. \& AD. NEws (98 Stat.) 494, 1045-46; id. $\$ 1033$ (deferral of gain on involuntary conversions), amended by Deficit Reduction of 1984, Pub. L. No. 98-369, § 474(r)(24), 1984 U.S. CODE CONG. \& AD. News (98 Stat.) 494, 844.

163. See id. $\S 267$ (loss on sale to related party), amended by Deficit Reduction Act of 1984, Pub. L. No. 98-369, $\$ \S 174($ a), (b), 721(s), 1984 U.S. Code ConG. \& AD. NEws (98 Stat.) 494, 70407, 970-71; id. $\$ 1091$ (1982) (wash sales of securities), amended by Deficit Reduction Act of 1984, Pub. L. No. 98-369, § 106(b), 1984 U.S. Code CoNG. \& AD. News (98 Stat.) 494, 629.

164. See supra note 130 and accompanying text.

165. Century Elec. Co. v. Commissioner, 192 F.2d 155, 159 (8th Cir. 1951), cert. denied, 342 U.S. 954 (1952). See generally 2 B. BitTker, Federal TaXation OF InCOME, Estates and GifTs \4 4.1.1 (1981).

166. Treas. Reg. $\$ 1.1002-1$ (c) (1960). I.R.C. $\$ 1002$ was repealed by the Tax Reform Act of 1976, Pub. L. No. 94-455, $\S 1901$ (b)(28)(B)(i), 90 Stat. 1520, 1799. However, the legislative history of the repeal indicates that the substance of $\S 1002$ was inerely moved to $\S 1001$ (c). See H.R. REP. No. 658, 94th Cong., $2 \mathrm{~d}$ Sess. 391 ("This amendment transfers to section 1001(c) of the Code the rules relating to recognition of gain or loss now in section 1002 of the Code."), reprinted in 1976 U.S. Code Cong. \& AD. News 2897, 3288. 
considers an asset obtained through a nonrecognition exchange as "substantially a continuation of the old investinent still unliquidated."167 In other words, the new asset is treated as if it were the old asset; it is given the same basis and the same tax attributes. ${ }^{168}$ Since the newly acquired asset has the same basis, any recogmition of gain on the exchange is postponed. By postponing realization in these cases, the tax systein overlooks the disposition.

Under the second sort of transaction, there is economic continuity in the taxpayers involved. For exainple, in a tax-free corporate reorganization, the resulting entity steps into the shoes of its coinponent corporations. Although the component parts distribute their assets to the inerged whole, it is treated for tax purposes as the saine entity as its parts. As the regulations state, "in the case of reorgamizations, . . . the new enterprise, the new corporate structure, and the new property are substantial continuations of the old still unliquidated." 169 Thus, such distributions are not treated as dispositions for the purposes of the asset-based tax benefit rule.

These two parallel notions, substantial continuity of property and substantial continuity of ownership, are theoretically identical for purposes of applying the asset-based tax benefit rule. In both cases, there has been no disposition of the asset in the eyes of the Code, and the rule will not be triggered. This standard can be easily applied to coinmon transactions. For exainple, in a like-kind exchange, the new asset acquires the basis of the old asset. In a reorganization, the new entity takes the old entity's place, creating an identity between the two, and precluding taxation of the distribution that has taken place. Changes in the form of the taxpaying entity include tax-free incorporations, ${ }^{170}$

167. Treas. Reg. \& 1.1002-I(c) (1960).

168. The substitute asset does not retain all the tax attributes of the disposed asset. For example, in a like-kind exchange of improved for unimproved real property, the new asset, unimproved property, will not be depreciable just because the old property was. See Treas. Reg. \$ 1.1031(a). I(b) (1967). However, the unimproved real estate will retain depreciation recapture potential. I.R.C. $\$ \S 1245(\mathrm{~b})(4), 1250(\mathrm{~d})(4)$ (1982).

169. Treas. Reg. § 1.1002-1(c) (1960); see supra note 166.

170. I.R.C. $\$ 351$ (1982); see also id. $\$ 1245$ (b)(3) (exception to depreciation recapture). By so characterizing nonrecognition transactions, the asset-based tax benefit rule excludes the logical extension of Nash v. United States, 398 U.S. 1 (1970). See supra notes 151-55 and accompanying text. In the eyes of the Hillsboro Court, there was no inconsistent event in Nash because the bad debt reserve was admittedly reasonable. Hillsboro Nat'1 Bank v. Commissioner, $103 \mathrm{~S}$. Ct. 1134, 1147 (1983); see Nash, 398 U.S. at 4. By negative imphcation, the Hillsboro Court's treatment of Nash could inean that the tax benefit rule should apply to an incorporation of a business with an unreasonable bad debt reserve. The asset-based approach does not allow such a result, because a tax-free incorporation is treated as a nonrecognition event. The nature and extent of this asymmetry in the asset-based approach are greatest in the imreasonable bad debt reserve situation. Thus, the asset-based tax benefit rule trades exact taxation for a clearly defined and easily applicable rule. The deductions for the reserve are taken at the unincorporated rate, but the adjustments to 
tax-free reorganizations, ${ }^{171}$ liquidations of subsidiaries, ${ }^{172}$ contributions of property to partnerships, ${ }^{173}$ and partnership distributions. ${ }^{174}$ Substitution of substantially unliquidated assets includes like-kind exchanges. ${ }^{175}$ In each of these transactions, there is econoinic continuity between the owners of the assets or between the assets theinselves. Consequently, the asset-based tax benefit rule will not be triggered.

\section{E. Realization, Recognition, and the Asset-Based Tax Benefit Rule}

The asset-based tax benefit rule produces tax in soine new situations, and thus inay expand generally accepted notions of permissible taxation. This Section explores the consonance of the proposed approach witl current realization and recognition doctrines and concludes that the rule satisfies both requireinents. Its treatment of all

the reserve (and any income from debts previously written off) will be taxed at the corporate rate. This allows a limited opportunity for income splitting.

The unattractiveness of this result is mitigated by two factors. First, the bad debt reserve must have been thought to have been reasonable when it was established, or it would not have been allowed. If it was unreasonable when it was established and the taxpayer knew this but misrepresented the facts to the Service, slie could be subject to prosecution for tax fraud. See generally I.R.C. $\$ \S 7201-7207$ (1982), amended by Deficit Reduction Act of 1984, Pub. L. No. 98369, $\$ \S 159$ (a), 412 (b)(9), 1984 U.S. CODE CoNG. \& AD. NEws (98 Stat.) 494, 696, 792. Moreover, the Service lhas contmuous opportunities to readjust the reserve to a reasonable level by denying additions to it. Second, the potential for income splitting is not otherwise unknown to the tax benefit rule. If a taxpayer incorporates with expensed assets in the business, and the corporation then disposes of the assets, the tax thereon will be computed at the corporate rate. And, if a taxpayer recovers a deduction in a later year, even without an intervening incorporation, her tax bracket may have changed, thus producing a net gain or loss on tax. Compare Perry v. United States, 160 F. Supp. 270 (Ct. Cl. 1958) (exact tax rate correlation), with Alice Phelan Sullivan Corp. v. United States, 381 F.2d 399 (Ct. Cl. 1967) (overruling Perry, allowing bracket changes). See supra note 12.

171. See I.R.C. $\S 368$ (1982), amended by scattered sections of Deficit Reduction Act of 1984, Pub. L. No. 98-369, 1984 U.S. CODE CONG. \& AD. News (98 Stat.) 494; id. \& 381, amended by Deficit Reduction of 1984, Pub. L. No. 98-369, §§ 211(b)(4), 474(r)(11), 1984 U.S. CODE CONG. \& AD. NEwS (98 Stat.) 494, 754, 841; see also id. $\$ \$ 354($ b), 355 (certain tax-free divisive reorganizations).

172. See id. $\S \S 332,334($ b). In sucl a liquidation, the parent takes a carryover basis, $\S 334(b)$, and the depreciation recapture rules are not triggered.

173. I.R.C. $\$ 721$ provides that: "No gain or loss shall be recognized to a partnership or to any of its partners in the case of a contribution of property to the partnership in exchange for an imterest in the partnership." See also id. \& 1245(b)(3) (exception to depreciation recapture).

174. I.R.C. $\$ 731$ (1982) generally provides for nonrecognition of gain on property distributious up to the partner's basis in the partnership interest. I.R.C. $\$ 731$ is also mitigated by I.R.C. \$1245(b)(3), exempting depreciation recapture. But see id. \& 751 (collapsible partnership provisions), amended by scattered sections of Deficit Reduction Act of 1984, Pub. L. No. 98-369, 1984 U.S. CODE CoNG. \& AD. NEws (98 Stat.) 494; id. \& 386 (transfer of partnership interests by corporations), added by Deficit Reduction Act of 1984, Pub. L. No. 98-369, § 75(a), 1984 U.S. CoDE Cong. \& AD. NEws (98 Stat.) 494, 594.

175. Id. \& 1031, amended by Deficit Reduction Act of 1984, Pub. L. No. 98-369, \& 77(a), 1984 U.S. CODE CONG. \& AD. NEws (98 Stat.) 494, 595-96. Like-kind exchanges are also exempt from depreciation recapture, except to the extent of non-1245 property or boot received. See id. \& 1245(b)(4). 
dispositions of assets as realization events, and requirement of partial recognition upon this realization, has both congressional and judicial support. The scope of federal mcone taxation is limited only by the sixteenth amendment to the United States Constitution. ${ }^{176}$ In Eisner $v$. Macomber, ${ }^{177}$ the Suprenie Court construed the term "income" under the sixteenth amendnient to niean "soinething of exchangeable value proceeding from the property, severed from the capital . . . received or drawn by the recipient," 178 not a gain inerely accrumg to capital, or a growth in the value of capital. The present construction of this general constitutional rule limits it to the notion that Congress cannot tax the appreciation in value of an asset until sonre occurrence or transaction that niay be construed as a realization event lias occurred. ${ }^{179}$ The definition of a realization event niay be quite broad, ${ }^{180}$ but such an event is still constitutionally required before gam may be taxable.

Nevertheless, an event may be taxable, yet not taxed. Althougl a realization has occurred, no tax will be produced unless the gam, if any, is recognized-that is, specified for taxation in the Code. ${ }^{181}$ Generally, the federal inconie tax system taxes all realized gains unless a specific Code section provides to the contrary. ${ }^{182}$

\section{Realization and the Asset-Based Tax Benefit Rule}

In its most basic form, the asset-based tax benefit rule treats all dispositions as realization events. In doing so, the rule relies on numerous exaniples from the Code for an expansive interpretation of the rule of realization. Section 1001, which defines the meclianism for determining whether gam or loss is realized, encompasses gains from "the sale or other disposition of property." 183 Section 453B, covermg the disposition of imstallment obligations, provides for realization when such an obligation is "distributed, transmitted, sold, or otherwise disposed

176. See supra note 7 .

177. 252 U.S. 189 (1920).

178. Id. at 207 (emphasis in original).

179. See B. Bittker, L. Stone \& W. Klein, Federal Income Taxation 298 (1984). Professor Chirelstein argues that the Eisner v. Macomber requirement is purely administrative, and that "Congress is free to treat gains and losses as 'realized" pretty much whenever it chooses." M. ChIRELSTEIN, supra note 161, I 5.01 at 69.

180. Indeed, as one commentator noted, the courts have treated the Supreme Court's pronouncement quite narrowly: "Each succeeding opimion paid its respects to the principle of realization which was the core of the Court's pronouncement in Eisner v. Macomber, but went on to a result which never matched the rigor of that pronouncement." Surrey, The Supreme Court and the Federal Income Tax: Some Implications of the Recent Decisions, 35 ILL. L. REv. 779, 782 (1941).

181. See M. Chirelstein, supra note 161, at 226-27.

182. See I.R.C. $\S 1001$ (c) (1982) (realized gain recoginzed unless otherwise provided).

183. Id. $\S 1001$ (b) (emphasis added). 
of." 184 Section 311(d), as amended by the Tax Reform Act of 1984, treats the distribution of property from a corporation to its shareholders as a constructive sale, ${ }^{185}$ a classic example of a realization event. ${ }^{186}$ Each of these sections treats a disposition as a realization event.

Court rulings in the tax shelter area further demonstrate the breadth of the treatunent of a disposition as a realization event. Tax shelters present probleins similar to those found in classic tax benefit rule situations. Often, the asset in a tax shelter is highly leveraged: after the owner of the asset has taken depreciation deductions on it for several years, its basis is far below its market value. The potential gain on the asset has been affected by these deductions, as im inost tax benefit situations. Moreover, as with the proposed tax benefit rule, many transactions involving the tax shelter asset but not involving a classic sale, exchange, or disposition will be realization events. As tax shelters have become inore abused, courts have stretched the scope of the "taxable event" (and thus the realization requirement) by finding gifts, abandonments, and changes in trust provisions to be realization events.

For exaunple, a gift does not usually produce tax to the donor. ${ }^{187}$ Any event producing tax, however, must be a recogmition event, simce taxation means the Code has recognized any gain or loss realized on the transaction. A fortiori, it must be a realization event. ${ }^{188}$ In the tax shelter area, a gift can be a realization event. For example, if a taxpayer makes a personal gift of a tax shelter with habilities in excess of basis, the transaction will be treated partially as a gift and partially as a sale. ${ }^{189}$ The result is similar with gifts to charity. Although the taxpayer receives a deduction for such a gift, the amount by which liabili-

184. Id. $\$ 453 \mathrm{~B}$ (a) (emphasis added), amended by scattered sections of Deficit Reduction Act of 1984, Pub. L. No. 98-369, 1984 U.S. CODE CONG. \& AD. NEws (98 Stat.) 494.

185. Id. §311(d), amended by Deficit Reduction Act of 1984, Pub. L. No. 98-369, § 54(a), 1984 U.S. Code CoNG. \& AD. News (98 Stat.) 494, 568-69.

186. See generally M. ChIRELstein, supra note 161 , f 5.01 at 69-71.

187. See I.R.C. $\$ 102$ (1982) (exclusion of gift from donee's imcome); id. $\S 1015$ (carryover basis), amended by Deficit Reduction Act of 1984, Pub. L. No. 98-369, § 421(b)(5), 1984 U.S. CODE CONG. \& AD. NEws (98 Stat.) 494, 794. Together, these sections provide the negative inference that the donor is not taxed on the appreciated value of a gift. This only means, however, that any gain reahzed on the making of a gift is recognized. See generally M. CHiRELsTeIN, supra note 161, If 5.01 at 69.

188. The structure of I.R.C $\$ 1001$ (1982) requires realization before recognition.

189. See Malone v. United States, 326 F. Supp. 106 (N.D. Miss. 1971), affd per curiam, 455 F.2d 502 (5th Cir. 1972); Johnson v. Commissioner, 59 T.C. 791 (1973), affd, 495 F.2d 1079 (6th Cir.), cert. denied, 419 U.S. 1040 (1974); see also Ginstling, Getting Out of Tax Shelters Through Bankruptcy and Other Techniques: A Timely Update, 38 N.Y.U. INST. ON FED. TAX'N $\$ \$ 33,33.11$ (1980); Podolin, How to Handle the Burned Out Tax Shelter, 37 N.Y.U. INST. ON FED. TAX'N $\S \S 16,16.03[1][1]$ (1979); Whitmire, Bailing Out of Tax Shelters: Selected Techniques, 1978 S. CAL. TAX INsT, 503, 508. But see Commissioner v. Turner, 410 F.2d 752 (6th Cir. 1969) (per curiam) ("net gift"); Hirst v. Commissiouer, 63 T.C. 307 (1974), affd per curiam en banc, 572 F.2d 427 (4th Cir. 1978). 
ties exceed basis will be treated as a bargain sale and will potentially produce income. ${ }^{190}$

The abandonment of a tax shelter can also produce realized gam or loss. When a taxpayer walks away from an asset, he is neitler selling it nor disposing of it in the classic sense-what has occurred is nore like a nontransaction. Nevertheless, abandonment can be a realization event when the asset's liabilities exceed its basis. ${ }^{191}$

Perhaps the most unconventional realization event in the disposition of a tax shelter is the grantor trust strategy. Under this approacl, the taxpayer places the tax shelter in a grantor trust. ${ }^{192}$ In the early years, the tax shelter produces deductions, which flow tlirough the trust to the taxpayer-grantor. Later, when the tax shelter begins to produce imcoine, the trust converts to a nongrantor type, ${ }^{193}$ and the incoine (and deductions) reinam the property of the trust. The Internal Revenue Service has held such a conversion to be a realization event for the grantor. ${ }^{194}$

Although conversions seein extreinely remote froin the constitutionally required "severance" of incoine from capital, current theory does provide for realization upon conversion. For example, section 179(d)(10) allows for "recapturing the benefit under any deduction allowable under subsection (a) with respect to any property which is not used predominantly im a trade or business at any time before the close of the second taxable year . . . in which it is placed in service by the taxpayer." Thus, if a taxpayer converts an asset expensed under section 179 to personal use, it will no longer be "used predoininantly im a trade or busmess," and it will thus be subject to recapture. Even if such a conversion does not actually produce a tax, it is a realization event because it is subject to tax.

The provisions and regulations governing the investment tax credit allow the most extensive application of the conversion realization theory. Section $47(\mathrm{a})(1)$ mandates recapture of the imvestment tax credit

190. Rev. Rul. 75-194, 1975-1 C.B. 80; see I.R.C. $§ 1011$ (b) (1982); Treas. Reg. $\$ 1.1011-2$ (1980); see also Ginstling, supra note 189, at § 33.11; Podolin, supra note 189, at § 16.03[1][e].

191. See generally Ginsburg, The Leaky Tax Shelter, 53 TAXEs 719, 733-34 (1975). This possibility is supported by the famous footnote 37 in Crane v. Commissioner, 331 U.S. 1, 14 n.37 (1947): "[A] different problem might be encountered where a mortgagor abandoned the property or transferred it subject to the mortgage without receiving boot." It does not matter that the liability is nonrecourse. See Commissioner v. Tufts, 103 S. Ct. 1826 (1983).

192. See generally Cowan, Use of Grantor Trusts to Escape a Tax Shelter Without Detrimental Tax Effects, 41 J. TAX. 346 (1974); Whitmire, supra note 189, at 514-30. But see Edgar v. Comnnissioner, 56 T.C. $717,759-62$ (1971).

193. This may occur through expiration of those retained powers that caused the trust to be deemed a grantor trust, through renunciation by the grantor, or by the terms of the trust itself. See Whitmire, supra note 189 , at 516 .

194. Rev. Rul. 77-402, 1977-2 C.B. 222. 
during the taxable year when "property is disposed of, or otherwise ceases to be section 38 property with respect to the taxpayer." Section 38 property is defined as tangible personal property subject to depreciation, so if property is converted to personal use, it will no longer be subject to depreciation ${ }^{195}$ and will therefore "cease to be section 38 property." Recapture will thus be triggered. And since tax will be produced by the recapture, the conversion must be a realization event, as well as a recognition event.

The asset-based tax benefit rule thus rehes on sohd precedent when it treats all dispositions as realization events.

\section{Recognition and the Asset-Based Tax Benefit Rule}

As the above analysis indicates, any event that produces tax is a recognition event, and a fortiori, a realization event. But the converse is not true: a realization event is not always a recogintion event. Although Congress can tax a particular transaction, it may choose not to do so. Alternatively, it may subject the transaction to only partial taxation. As a result, recogintion is determined by what Congress chooses to do. Once again, the asset-based tax benefit rule finds support for its recogintion approach in the Code and the case law.

The proposed rule treats any disposition or conversion as a constructive sale in order to recapture previous tax benefits. If the constructive sale produces gam, that gain is recognized. The asset-based tax benefit rule, however, causes only limited recognition. Although a disposition may trigger realization of the entire gain (calculated by the excess of the amount realized over adjusted basis ${ }^{196}$ ), the asset-based tax benefit rule requires recognition only to the extent required to recoup the tax benefit previously gained. If the asset has depreciated in value from its origmal basis, realization and recognition will be coextensive. If the asset has appreciated in value, the gain realized may be greater than the gain recognized. 197

For example, if a farmer buys $\$ 10,000$ worth of cattle feed, he may immediately deduct its cost. The basis in the grain will then be zero. If the farmer makes a personal gift of the grain in a subsequent year, and it has appreciated in value, his recognition of gain will be limited to his original tax deduction - the cost of the grain. The realized gain on the market appreciation will not be recognized, as such gain does not reflect

195. Property is subject to depreciation only if used in a trade or business, or for the production of income. I.R.C. \& 167(a) (1982).

196. See id. \&1001(a).

197. If the taxpayer has taken deductions that affect fair market value, realization and recognition will be coextensive only if the increase in fair market value equals the sum of the deductions. 
the tax benefit previously received. Conversely, if the grain has depreciated in value, the farmer's recognized gain will equal his realized gain - the excess of the fair market value of the grain over its basis. Recognition is limited to realization, as it necessarily must be. ${ }^{198}$ In this way, the asset-based tax benefit rule will avoid the recognition of gain due to market appreciation, ${ }^{199}$ forcing taxpayers to recognize gain less than or equal to the origmal tax benefit.

Congress and the courts generally apply a similar approach to other tax benefit situations. For example, section 179(d)(10), which allows expensing beyond depreciation, produces tax only on "the benefit under any deduction allowable." Section $47(a)(1)$ recaptures only the investment tax credit rather than gain due to market appreciation of the asset itself. Furthermore, courts treat the shedding of nonrecourse liabilities $\mathrm{m}$ the disposition of a tax shelter as gam. These liabilities were the source of prior deductions, and thus were the source of the tax benefit. But if a tax shelter is abandoned, recogmized gam is limited to habilities shed. ${ }^{200}$ There is no taxation of appreciation in fair market value due to market forces. On the other hand, section 311(d), as amended im 1984, ${ }^{201}$ which regulates corporate distributions, and section 453B, which regulates the disposition of installment obligations, employ a more complete constructive sale concept. ${ }^{202}$ These sections tax gain flowing solely from increases im fair market value. Recognition to this extent goes beyond the recognition called for in the asset-

198. Recognition, as required by I.R.C. $\$$ I00I(c) (1982), cannot exceed realization, I.R.C. $\S 1001$ (a) (1982), by the very nature of the Code. Since realization defines gain from the disposition of property, and thus incone, recognition in excess of realization may violate the I6th amendinent.

199. But the asset-based tax benefit rule does recognize gain due to prior expenses that enhance fair market value, as distinguished from pure market forces.

200. See Ginsburg, supra note 191, at 733-34; Podolin, supra note 189, at § 16.03[1][b].

201. Deficit Reduction Act of 1984, Pub. L. No. 98-369, § 54(a), 1984 U.S. Code Cono. \& AD. NEws (98 Stat.) 494, 568-69.

202. I.R.C. $\$ 453 \mathrm{~B}$ (a) (1982) provides that when

an installment obligation is satisfied at other than its face value or distributed, transmitted, sold, or otherwise disposed of, gam or loss shall result to the extent of the difference between the basis of the obligation and-

(1) the amount realized, in the case of satisfaction at other than face value or a sale or exchange, or

(2) the fair market value of the obligation at the time of distribution, transmission, or disposition ....

Thus, § 453B will provide for recognition of narket value gams, unless some nonrecognition provision applies. To this extent, it provides for more recognition than does the asset-based tax benefit rule.

Similarly, and more straightforwardly, I.R.C. \$311(d)(1) (1982), as amended by Deficit Reduction Act of 1984, Pub. L. No. 98-369, § 54(a)(1), 1984 U.S. CODE CONG. \& AD. News (98 Stat.) 494,568 , generally provides that when a corporation distributes appreciated property, "gaim shall be recognized to the distributing corporation in an amount equal to [the excess of the fair market value of the property over its adjusted basis] as if the property distributed had been sold at the time of the distribution." 
based tax benefit rule and should be delimited only by Congress. The asset-based tax benefit rule is a judicial rule designed only to remedy certain inequities in the tax system, and once the tax benefit has been removed, the inequity is gone. Congress may choose to tax more if it desires; but it is not the role of the courts to do so.

Fimally, the asset-based tax benefit rule, by exempting from its application the class of nonrecognition events roughly described as "economic contmuity" transactions, follows the general lead of section 47, which governs investment tax credit recapture. Section 47(b) provides a broad exception to this recapture provision:

property shall not be treated as ceasing to be section 38 property with respect to the taxpayer by reason of a mere change in the form of conducting the trade or business so long as the property is retained in such trade or business as section 38 property and the taxpayer retains a substantial interest in such trade or business. ${ }^{203}$

The reason for this exception is clear: "it [is] necessary to forego the application of the adjustment rule only . . . in the case of corporations where a successor corporation 'stands in the shoes' of the predecessor corporation." 204 In the terms of the asset-based tax benefit rule, the new corporation is substantially a continuation of the old corporation still unliquidated. ${ }^{205}$

\section{CONCLUSION}

The proposed asset-based model differs from the Hillsboro rule in several respects. The Hillsboro mconsistent events approach throws out the good with the bad by abandoning the recovery approach in favor of an entirely new theory. In contrast, the asset-based rule works concurrently with the recovery approach, reaching only those situations in which the classic approach fails: dispositions of assets upon which deductions have been taken. Thus, the recovery rule is left to operate in

203. Id. $\S 47$ (b) (emphasis added); see also Treas. Reg. $\S 1.47-3(\mathrm{a})$ (1972).

204. S. REP. No. 1881, 87th Cong., 2d Sess. 24, reprinted in 1962 U.S. CODE CONG. \& AD. NEws 3297, 3321 (emphasis added).

205. This approach has been implemented in at least one other country. In West Germany, if business assets are taken from the busmess and used for personal purposes, the fair market value of such assets is included im the individual's taxable income. "Withdrawals" are "all business assets (cash, goods, products, services and uses) which the taxpayer withdraws from the business to be used by himself, his household, or for other purposes foreign to the business." H. DEBATIN, ANALYSIS of the German TAX SYSTEM 39 (1969). The taxpayer is taxed on profits, which are defined as "[ $t$ ]he amount of the difference between the business capital at the end of the commercial year, and the business capital at the end of the preceding coinmercial year, increased by the value of withdrawals therefrom, and decreased by contributions thereto." Id. at 38 (einphasis added) (footnote omitted); see also Foreign TAX Law Association, Inc., TAX Laws of THE World: West Germany 37 (1982). See generally Price Waterhouse \& Co., Doing Business IN GERMANY 64-126 (1978). 
situations in which it has been successful for years: all nonasset transactions.

This asset-based rule also has the advantage of clearly defined boundaries. ${ }^{206}$ It is unclear when the inconsistent events approach adopted by the Hillsboro Court will be invoked, and the Court leaves unresolved the myriad conflicts between the tax benefit rule and nonrecognition provisions. The asset-based model applies in clearly defined situations and takes nonrecognition policies into account in the definition of a disposition. The asset-based approach also defines how much mcome a taxpayer will recognize-one of the questions left unanswered in the Hillsboro opinion. The taxpayer will recognize the amount of the prior deduction, up to the amount the taxpayer reahizes on the disposition. This formula is not only clear, but it shifts the central inquiry from the original deduction year, as in the inconsistent events rule, to the year of disposition. Rather than provoke speculation on whether the deductions would have been allowed had certain events occurred in the past, the asset-based approach asks taxpayers a question they always face-will this disposition cause income to be recognized this year?

By impleinentimg an asset-based approach, the proposed rule avoids the difficulties inherent in the Hillsboro Court's theory. It supphes a simple and easily implemented approach. It responds to the problems that spurred the creation of the tax benefit rule by achieving parity among taxpayers, by clearly reflecting incone, and by recognizing the congressional policy choices inherent in the nonrecognition provisions of the Code.

William R. Lindsay*

206. When a taxpayer disposes of an asset after having taken a deduction that did not directly affect that asset's basis, the asset-based rule provides only a general guide as to whether there should be a tax benefit recovery. In encouraging a court to determine whether substantially all of the deduction affects basis, the asset-based tax benefit rule evokes line-drawing probleins and falls subject to soine of the saine criticisins leveled against the inconsistent events approach. But in this area, the rule is susceptible of no inore certainty. Courts must do what is fair and equitable on the facts of each case. And the proposed approach does give taxpayers a standard to apply so that they may plan their actions according to their expected tax liability. See supra note 147.

- B.A. 1981, Dartmouth College; third-year student, Boalt Hall School of Law, University of California, Berkeley. 